\title{
ANALISIS HUKUM EKONOMI SYARIAH TERHADAP PRAKTEK GADAI LAHAN SAWIT DI KECAMATAN GUNUNG TULEH KABUPATEN PASAMAN BARAT
}

\author{
M. Yarham \\ e-mail : myarhamlubis@gmail.com
}

\begin{abstract}
Artikel ini bertujuan untuk menegetahui dan menganalisa bentukbentuk akad gadai yang digunakan oleh masyarakat Kecamatan Gunung Tuleh dalam melakukan praktek gadai lahan sawit dan untuk mengetahui dan menganalisa tinjauan hukum ekonomi syariah terhadap bentuk bentuk-bentuk akad gadai yang digunakan oleh masyarakat Kecamatan Gunung Tuleh. Jenis penelitian ini menggunakan jenis penelitian lapangan (field research) dengan metode penelitian kualitatif. Teknik pengumpulan data dalam penelitian ini adalah wawancara dan dokumentasi. Teknik analisis data yang digunakan dalam penelitian ini adalah reduksi data (data reduction), penyajian data (data display) serta penarikan kesimpulan dan verifikasi. Berdasarkan hasil penelitian, diperoleh kesimpulan bahwa dalam praktek gadai lahan sawit di Kecamatan Gunung Tuleh Kabupaten Pasaman Barat dilihat dari segi akadnya tidak sesuai dengan ketentuan hukum Islam khususnya hukum ekonomi syariah. Tidak sesuai akad tersebut terjadi pada sighat akad pada ijab kabl yang mensyaratkan pemanfaatan barang gadai, adanya biaya tambahan yang harus diberikan penggadai (rahin) dengan sejumlah uang tertentu dalam melunasi utangnya. Hukum ekonomi syariah menyebutkan bahwa shighat gadai tidak boleh digantungkan dengan syarat, dan tidak disandarkan kepada masa yang akan datang. Apabila akad gadai (rahn) digantungkan dengan syarat atau disandarkan kepada masa yang akan 31ating, maka akad akan fasid (rusak), seperti adanya biaya tambahan yang harus diberikan dalam penebusan utang gadai yang dicantumkan dalam akad dengan mengacu kepada kaidah fiqh " setiap utang yang menarik manfaat, maka ia termasuk riba".
\end{abstract}

Keywords : Analisis Hukum, Akad, Gadai

PENDAHULUAN

Islam dalam aspek muamalah mengajarkan kepada umatnya untuk saling tolong menolong dalam berbagai hal terhadap sesama manusia terlebih lagi terhadap saudara seiman. Mengingat kodrat manusia adalah selain berperan sebagai makhluk individu juga 
berperan sebagai makhluk sosial. Oleh sebab itu dalam kehidupan bermuamalah sudah sewajarnya orang yang kaya menolong orang yang miskin dan orang yang mampu harus menolong orang yang kurang atau tidak mampu. Bentuk tolongmenolong dalam hal ini dibedakan menjadi dua jenis, yaitu berupa pemberian dan berupa pinjaman yang biasa disebut dengan utang piutang.

Utang piutang merupakan salah satu bentuk transaksi dalam kegiatan ekonomi. Di mana satu pihak sebagai pemberi pinjaman memberikan objek pinjaman kepada pihak lain sebagai peminjam yang menerima atau membutuhkan objek pinjaman. Dalam ilmu ekonomi pihak yang memberikan pinjaman disebut dengan kreditur sedangkan pihak yang menerima pinjaman disebut sebagai debitur. Transaksi utang-piutang tersebut dapat disertai dengan jaminan ataupun tidak. Jaminan dalam transaksi utang-piutang berperan sebagai alat untuk berjaga-jaga apabila pihak debitur tidak mampu mengembalikan hutang kepada pihak kreditur. Jaminan tersebut biasanya berupa benda berharga atau memiliki nilai jual tinggi. Hal ini diperbolehkan dalam Islam dengan alasan mengandung prinsip kehati-hatian. Utang-piutang yang disertai dengan jaminan disebut dengan gadai atau dalam fiqh muamalah disebut dengan rahn. (Sutedi, 2011: 2)

Rahn secara etimologi berarti atstsubut wa ad-dawam yang artinya tetap dan kekal, dapat juga disebut alhabsu dan al-luzuum yang artinya menahan (jaminan) (Ghazaly, 2010: 265). Sedangkan secara istilah rahn menurut menurut Ibnu Qudhamah dalam Kitab al-Mughni adalah sesuatu benda yang dijadikan jaminan suatu utang, hingga orang yang bersangkutan boleh mengambil utang atau ia bisa mengambil sebagian (manfaat) barang itu (Qudamah, 1997: 115).

Penyerahan jaminan (marhun) dalam praktek gadai (rahn) dilakukan dalam bentuk suatu transaksi utangpiutang. Untuk sahnya suatu transaksi tersebut diperlukan suatu akad dengan cara penyerahan dan penerimaan atau cara lain yang menunjukkan telah berlangsungnya akad rahn dengan cara suka sama suka. Unsur-unsur yang terlibat praktek gadai (rahn) itu adalah: (Sutedi, 2011: 10)

1. Orang yang berutang dan menyerahkan barang berharga sebagai jaminan, disebut orang yang memberikan gadai (rahin)

2. Orang yang berpiutang dan menerima barang, disebut orang yang memegang barang gadai (murtahin) 
3. Barang yang digadaikan (marhun)

4. Ada utang, disyaratkan utang telah terjadi, jika barang yang digadaikan itu diterima oleh yang berpiutang dari yang berutang maka jadilah barang itu menjadi barang gadaian, yang punya barang tidak boleh menghilangkan barangnya demikian juga yang menerima barang, yang punya barang tidak boleh menjual barang gadaian tersebut kecuali izin pemberi utang. (Sutedi, 2011: 10)

Jika seseorang membutuhkan dana sebenarnya dapat diajukan ke berbagai sumber dana, seperti meminjam uang ke bank atau lembaga keuangan lainnya. Akan tetapi kendala utama adalah prosedur yang rumit dan memakan waktu yang relatif terlalu lama. Di samping itu persyaratan yang lebih sulit untuk dipenuhi seperti dokumen yang harus lengkap membuat masyarakat mengalami kesulitan untuk memenuhinya dan jarak tempuh yang sangat jauh. Begitu pula dengan jaminan yang diberikan harus barangbarang tertentu karena tidak semua barang dapat dijadikan jaminan di bank. Dengan demikian masyarakat pedesaan lebih mencari solusi dan beranggapan bahwa menggadaikan hartanya berupa lahan sawit kepada orang yang mempunyai keuangan bisa membantu kebutuhannya pada waktu itu.

Pengambilan manfaat pada benda-benda gadai ditekankan kepada biaya atau tenaga untuk pemeliharaan sehingga bagi yang memegang barangbarang gadai seperti hewan-hewan akan ada kewajiban tambahan. Tambahan terhadap barang gadaian dikarenakan makanan yang diberikan kepada barang yang digadaikan, jadi yang diperbolehkan dalam meminta biaya dalam barang gadaian apabila adanya upaya pemeliharaan dalam barang gadaian tersebut (Suhendi, 2010: 109).

Gadai adalah perjanjian pinjam meminjam dengan menyerahkan barang sebagai tanggungan. Allah SWT berfirman dalam surat alBaqarah ayat 283 yang berbunyi:

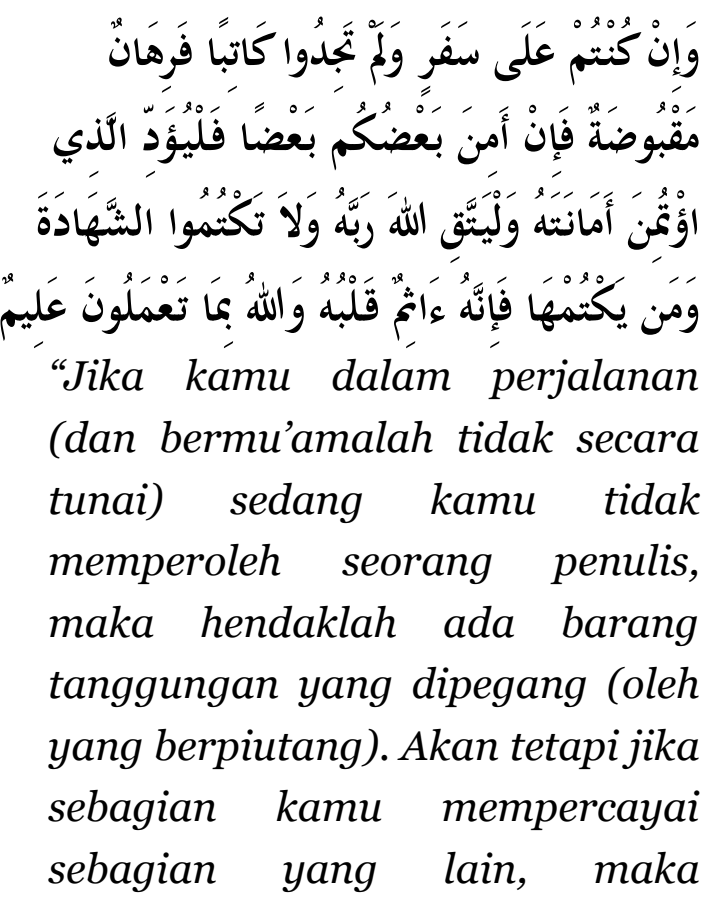


hendaklah yang dipercayai itu menunaikan amanatnya (hanya) dan hendaklah ia bertakwa kepada Allah Tuhannya; dan janganlah kamu (para saksi) menyembunyikan persaksian. Dan barangsiapa yang menyembunyikannya, maka sesungguhnya ia adalah orang yang berdosa hatinya; dan Allah Maha Mengetahui apa yang kamu kerjakan." (Kementerian Agama RI, Al-Qur'an dan Terjemahannya, surat Al-Baqarah: 283)

Gadai juga ada dalam hadis yang diriwayatkan oleh Bukhari, yaitu :

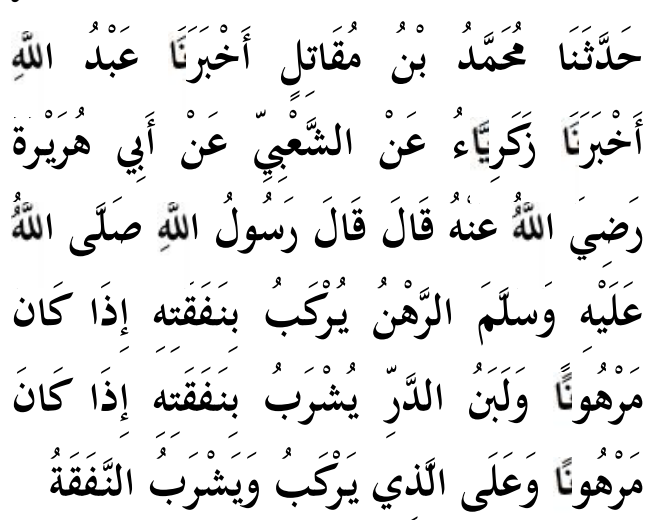

"Telah menceritakan kepada kami Muhammad bin Muqatil telah mengabarkan kepada kami 'Abdullah telah mengabarkan kepada kami Zakariya' dari AsySya'biy dari Abu Hurairah radliallahu 'anhu berkata; Rasulullah shallallahu 'alaihi wasallam bersabda: (Hewan) boleh dikendarai jika digadaikan dengan pembayaran tertentu, susu hewan juga boleh diminum bila digadaikan dengan pembayaran tertentu, dan terhadap orang yang mengendarai dan meminum susunya wajib membayar." (H.R Bukhari) (Bukhari, 1996: 161).

Ayat dan hadis di atas menjelaskan bahwa praktek gadai dibolehkan dan sudah dipraktekkan semenjak masa Rasululullah Saw. Khususnya pada pada hadis di atas dijelaskan oleh Rasulullah Saw bahwa boleh memanfaatkan harta gadai untuk keperluan pemeliharaan dan perawatan harta gadai tersebut. Hal ini disebutkan pada hadis bahwa jika hewan dikendarai apabila digadaikan dengan pembayaran tertentu, maka hewan tersebut boleh ditunggangi dan diperah susunya.

Pelaksanaan gadai lahan sawit di Kecamatan Gunung Tuleh Kabupaten Pasaman Barat dilakukan dengan menggunakan batas waktu dan ada juga yang tidak mempunyai batas waktu. Kemudian adanya tambahan angsuran terhadap penggadai (rahin) serta lahan sawit yang digadaikan akan menjadi milik penerima gadai (murtahin) apabila tidak bisa melunasi hanya sampai batas waktu yang diperjanjikan. Dalam adat Mandailing gadai merupakan hubungan hukum yang timbul antara 
seseorang dengan tanah khususnya lahan sawit kepunyaan orang lain yang telah menerima uang gadai darinya. Selama uang gadai belum dikembalikan, tanah tersebut dikuasai oleh penerima gadai. Selama itu hak atas tanah seluruhnya menjadi hak penerima gadai. Pengembalian uang gadai atau yang lazim disebut "penebusan", tergantung kepada kemauan dan kemampuan pemberi gadai. Objek barang gadai adalah barang tidak bergerak seperti lahan sawit, sawah, ladang dan lain sebagainya.

Proses gadai tersebut dilakukan dengan cara yang sederhana yaitu si A yang akan menggadaikan lahan sawitnya kepada si B yang akan memberikan pinjaman uang. Dengan waktu pengembalian pinjaman ada yang ditentukan dan tidak ditentukan waktunya. Kemudian lahan sawit tersebut berpindah tangan dengan diserahkan kepada si B atau pemberi utang. Lahan sawit yang menjadi jaminan tersebut berada dalam penguasaan pemberi utang sampai pelunasan utang. Hasil panen yang melimpah dari lahan sawit pun menjadi hak pemberi utang sepenuhnya. Terkadang apabila utang belum terlunasi mencapai waktu bertahun-tahun sehingga hasil keuntungan dari hasil sawit itu sudah lebih besar dari nilai utang yang dipinjamkan. Bahkan apabila utang belum bisa dilunasi oleh penggadai (rahin) maka lahan sawit yang digadaikan pada akhirnya menjadi milik penerima gadai (murtahin).

Survey awal yang penulis lakukan menggambarkan bahwa masyarakat Kecamatan Gunung Tuleh hampir $70 \%$ pekerjaannya adalah sebagai petani sawit. Petani sawit bekerja untuk menghidupi kebutuhan keluarganya adalah sebagian besar dari lahan sawit. Namun masyarakat sering menggadaikan lahan sawitnya untuk kebutuhan sehari-hari atau mendapatkan modal untuk berusaha di bidang lain. Masyarakat menggadaikan lahan sawit kepada kerabatnya sendiri, tengkulak atau pemilik modal. Sudah ada beberapa kasus praktek gadai yang dilakukan oleh masyarakat Kecamatan Gunung Tuleh. (Kepala Jorong se-Kecamatan Gunung Tuleh, wawancara di Pasaman Barat, tanggal o2 Juli 2018).

Salah satu kasus gadai yang terjadi adalah Bapak Epa selaku penggadai dengan Bapak Akmam selaku penerima gadai yang sudah berlangsung sejak tanggal 20 Agustus 2015 sampai sekarang tanpa mempunyai batas waktu. Uang yang dipinjam penggadai (rahin) sebesar Rp. 40.000.000,- (empat puluh juta rupiah) dengan menggadaikan lahan sawitnya seluas 1 ha (hektar). Seluruh 
hak pengelolaan dan hasil dari lahan sawit tersebut menjadi milik pihak penerima gadai (murtahin) sampai utang tersebut ditebus oleh penggadai (rahin). Dalam isi perjanjian disebutkan bahwa penggadai (rahin) harus membayar uang tambahan sebesar Rp. 5.000.000,- (lima juta rupiah) dalam penebusan utang. (Epa, Penggadai, Wawancara, tanggal 12 Juli 2018).

Dari latar belakang di atas, penulis tertarik untuk membahasnya dengan judul : "Analisis Hukum Ekonomi Syariah Terhadap Praktek Gadai Lahan Sawit Di Kecamatan Gunung Tuleh Kabupaten Pasaman Barat”.

\section{METODE PENELITIAN}

Penelitian ini menggunakan metode penelitian kualitatif dengan jenis penelitian lapangan (field research), dalam hal ini memperoleh data tentang Analisis Hukum Ekonomi Syariah terhadap Prakktek Gadai Lahan Sawit di Kecamatan Gunung Tuleh Kabupaten Pasaman Barat yang mencakup tentang bentukbentuk praktek gadai yang digunakan dalam praktek gadai dan analisis hukum ekonomi syariah terhadap bentuk-bentuk praktek gadai tersebut. Sumber data primer dalam penelitian ini yaitu data yang diperoleh langsung dari lapangan melalui interview/wawancara di antaranya, penggadai (rahin) dan penerima gadai (murtahin). Sumber data yang diambil adalah bersifat sampel, sumber data dipilih secara purposive dan bersifat snowball sampling dan sumber data yang dipilih adalah orang yang terlibat langsung dalam praktek gadai lahan sawit tersebut. Sumber data sekunder yaitu data yang bersumber dari dokumen atau peraturan hukum yang menjadi acuan dasar alasan penelitian diluar data primer yang ada hubungannya dengan penelitian.

\section{HASIL PENELITIAN DAN PEMBAHASAN}

A. Bentuk-bentuk praktek gadai yang digunakan oleh masyarakat Kecamatan Gunung Tuleh Kabupaten Pasaman Barat.

Praktek gadai di Kecamatan Gunung Tuleh Kabupaten Pasaman Barat sudah menjadi tradisi sejak mulai adanya adat Mandailing atau yang disebut adat manjujur yang artinya dalam akitifitas kehidupan harus selalu menanamkan kejujuran. Bentuk praktek gadai yang terjadi di Kecamatan Gunung Tuleh dikenal dengan istilah manggadeon. Manggadeon ini terjadi ketika pemberi gadai telah menggadaikan lahan sawitnya kepada penerima gadai dan selanjutnya penerima gadai yang 
memegang, menguasai dan memanfaatkan serta mengelola lahan sawit tersebut sampai pemberi gadai menebusnya kembali.

Dahulu bentuk praktek gadai yang ada di Kecamatan Gunung Tuleh dilakukan antar karib kerabat atau famili, namun seiring perkembangan zaman gadai ini dilakukan atas dasar kebutuhan dengan orang yang punya uang seperti pemilik modal atau tengkulak tanpa ada sangkut paut pertalian darah. Barang yang dijadikan jaminan dalam gadai adalah lahan sawit dan yang dijadikan sebagai pinjaman kebanyakan dari masyarakat adalah uang dan emas.

Berdasarkan wawancara penulis dengan Bapak Maswizar Sitohang selaku Tokoh masyarakat bahwa praktek gadai yang terjadi di Kecamatan Gunung Tuleh disebabkan karena berbagai alasan, di antaranya adalah masalah ekonomi yang semakin sulit untuk terpenuhi, kebutuhan yang mendesak sehingga membutuhkan uang atau dana dalam waktu yang cepat, untuk modal usaha, biaya pendidikan, biaya berobat, biaya acara walimah atau pesta pernikahan (Maswizar Sitohang, wawancara, 20 Juli 2018).

Berdasarkan keterangan dari Tokoh Masyarakat di Kecamatan Gunung Tuleh yaitu Bapak Suparman Lubis gelar Sutan Lobe bahwa praktek manggadeon di Kecamatan Gunung Tuleh Kabupaten Pasaman Barat, dilakukan beberapa bentuk yaitu:

1. Gadai Salumpat Saindege artinya bahwa praktek gadai harus dilakukan dengan dasar tolong menolong bukan untuk kepentingan pribadi.

2. Gadai Taporan Batu artinya bahwa apabila melakukan praktek gadai harus ada jangka waktunya. Contohnya masa penebusan 1 tahun atau 2 tahun.

3. Gadai Siala Sampagul artinya bahwa seorang pemberi gadai meminjamkan tanahnya kepada si penerima gadai dengan syarat gadai ini hanya bisa dilakukan kalau orang tersebut bertali darah (ahli waris).

4. Gadai Panen artinya gadai yang berlangsung hanya berpatokan pada musim panen, dimana penggadai harus membayar atau menebus utangnya setelah memanen tanamannya.

5. Gadai Manotop artinya gadai hanya bisa dilakukan pada bulam muharram saja, karena disitu dimulai awal kehidupan yang baru. Namun, praktek ini tidak pernah dilakukan lagi. (Suparman Lubis gelar Sutan Lobe, Wawancara, tanggal 22 Juli 2018).

Gadai yang penulis teliti disini sebagian besar adalah bentuk gadai 
taporan batu artinya bahwa apabila melakukan praktek gadai harus ada jangka waktunya. Contohnya masa penebusan 1 tahun atau 2 tahun. Karena diantara surat perjanjian gadai yang ada di Kecamatan Gunung Tuleh telah disebutkan jangka waktunya, walaupun ada juga yang tidak disebutkan jangka waktunya dalam perjanjian.

Praktek gadai lahan sawit yang dilakukan oleh masyarakat Kecamatan Gunung Tuleh mempunyai ketentuanketentuan yang harus diikuti oleh setiap masyarakat yang melakukan praktek gadai sebagai berikut:

1. Orang yang melakukan praktek gadai harus sehat jasmani dan rohani

2. Harus ada keterangan jelas dari barang yang digadaikan. Contohnya sebidang lahan sawit harus jelas siapa pemiliknya dan bukti kepemilikannya seperti surat tanah.

3. Suka sama suka tanpa paksaan dari pihak lain. Dalam melakukan sebuah transaksi tentu kedua belah pihak telah memiliki niat untuk melakukan transaksi sesuai dengan keinginan hatinya. Apabila ada pihak lain yang memaksa atau salah satu pihak yang memaksa dalam transaksi tersebut maka transaksi yang dilakukan tidak dapat dikatakan sah atau belum bisa terlaksanakan karena salah satu pihak tidak rela untuk melakukan transaksi.

4. Besarnya nilai gadai (rahn) tergantung kesanggupan kedua belah pihak tanpa ada salah satu pihak yang dirugikan. Maksudnya disini adalah besarnya nilai dari barang yang digadaikan tergantung dari kesepakatan kedua belah pihak. Kedua belah pihak merundingkan dan bernegosiasi mengenai nilai barang gadai dan kesanggupan dari penerima gadai (murtahin) tersebut hingga tercapailah sebuah kesepakatan yang merupakan hasil akhir dari nilai barang (marhun) tersebut.

5. Harus dibuat surat dan diketahui oleh dua orang saksi. Dalam melakukan transaksi gadai, harus dilakukan pencatatan yang jelas dan terperinci dari kedua belah pihak, sebab transaksi gadai ini akan berlangsung lama hingga barang yang digadaikan dapat ditebus oleh rahin. Dalam melakukan akad dan pencatatan tertentu harus ada saksi yang menjadi penguat transaksi tersebut dan saksi juga berperan sebagai pembantu dalam pemecahan masalah apabila disuatu saat ada masalah pada transaksi gadai tersebut. (Marwazi gelar Raja Lubis, Wawancara, tanggal 23 Juli 2018) 
Berdasarkan keterangan Bapak Akmal selaku Tokoh Agama Kecamatan Gunung Tuleh mengatakan bahwa praktek gadai lahan sawit sudah turun-temurun dilakukan oleh masyarakat. Namun, seiring perkembangan zaman praktek gadai ini disalahgunakan dan nilainilai keislaman yang ada didalamnya mulai terkikis oleh nafsu materialisme. Sehingga praktek gadai ini dijadikan sebagai lahan bisnis oleh orang yang mempunyai uang, padahal dalam adat Mandailing atau yang disebut adat manjujur mengajarkan nilai-nilai kejujuran dan keislaman dalam melakukan praktek gadai yang tujuan utamanya adalah saling tolong menolong. (Akmal, Tokoh Agama, Wawancara, tanggal 29 Juli 2018).

Berkenaan dengan praktek gadai di Kecamatan Gunung Tuleh Kabupaten Pasaman Barat, terdapat beberapa pengertian gadai menurut masyarakat sebagai berikut:

1. Pengertian gadai menurut masyarakat

a. Gadai adalah praktek pinjam meminjam yang disertai dengan adanya jaminan dan pengusaan barang gadai berada pada penerima gadai.

b. Gadai adalah utang piutang yang disertai dengan jaminan. c. Gadai adalah bisnis pinjam meminjam untuk mendapatkan keuntungan.

d. Gadai adalah menahan salah satu harta milik penggadai (rahin) sebagai barang jaminan (marhun) atas pinjaman yang diterimanya.

e. Gadai adalah pemberian uang kepada penggadai yang disertai dengan jaminan dan adanya biaya tambahan yang harus diberikan pada waktu tertentu. Misalnya, tidak bisa melunasi sesuai waktu yang diperjanjikan.

2. Alasan masyarakat melakukan praktek gadai

Munculnya praktek gadai lahan sawit dalam masyarakat dilatar belakangi oleh kebutuhan akan uang tunai (cash money) yang dianggap mendesak untuk memenuhi kebutuhan yang mendesak. Untuk lebih rinci dan lebih jelasnya penulis akan memaparkan alasan pihak penggadai dan penerima gadai dalam melakukan praktek gadai lahan sawit:

a. Alasan penggadai menggadaikan lahan sawit

Masyarakat menggadaikan lahan sawit miliknya pada dasarnya disebabkan kebutuhan konsumtif dan kebutuhan produktif. Kebutuhan konsumtif, seperti 
kebutuhan akan belanja pesta pernikahan, biaya sekolah anak dan biaya berobat. Kebutuhan produktif seperti kebutuhan untuk mendapatkan modal usaha.

Keterangan dari responden yang menggadaikan lahan sawit menuturkan bahwa dia melakukan praktek gadai lahan sawit tersebut karena keperluan biaya perkawinan anaknya, kendati lahan sawit yang gadaikan tersebut merupakan sumber mata pencaharian keluarga mereka.

Di samping itu terdapat pula diantara masyarakat yang menggadaikan lahan sawit miliknya karena keperluan menambah modal kerja (modal usaha), pembelian barang untuk usaha produktif seperti pembelian pedati, dodos (alat pengambil sawit), maupun pembelian barang konsumtif seperti material bangunan rumah tinggal dan lainlain.

Namun dari sekian fenomena yang penulis temukan, masyarakat pada umumnya menggadaikan lahan sawit di sebabkan kebutuhan yang mendesak dalam skala konsumtif baik konsumtif primer maupun konsumtif sekunder yang dilakukan oleh masyarakat ekonomi lemah. Hal ini terbukti adanya masyarakat yang menggadaikan lahan sawit dan sudah berlangsung lama namun belum memiliki kemampuan untuk menebusnya kembali.

Berikut ini dapat diilustrasikan alasan penggadai menggadaikan lahan sawitnya sebagaimana data yang diperoleh di lapangan, yaitu:

1) Untuk memenuhi kebutuhan yang mendesak.

2) Untuk memperoleh dana tunai yang cepat dan tidak berbelit-belit.

3) Tidak terkejar waktu untuk membayar pokok maupun bunganya, seperti yang berlaku di beberapa lembaga keuangan

4) Lahan sawit yang digadaikan sewaktu-waktu dapat diambil kembali jika penggadai memiliki uang untuk menebusnya.

5) Penggadai memilih menggadaikan lahan sawitnya daripada menjualnya, karena sawah senantiasa mengalami harga yang meningkat setiap tahunnya.

b. Alasan penggadai untuk menerima tawaran gadai lahan sawit

Dalam praktek gadai lahan sawit, ada beberapa alasan seseorang melakukan dan menerima gadai sawah yaitu: 
1) Sebagai sarana untuk Yandra disebut sebagai pihak II menabung dengan cara (kedua) atau penerima gadai, umur 39 praktis. tahun, dan pekerjaan sebagai buruh

2) Untuk mendapatkan keuntungan yang lebih besar bahwa pihak I (pertama) atau dibanding menabung di bank. penggadai mengakui telah meminjam

3) Menambah penghasilan.

4) Menolong kerabat yang uang sebanyak Rp. 50.000.000,membutuhkan dana segar.

Namun, secara keseluruhan responden sepakat jika mendapat keuntungan merupakan faktor utama yang memotivasi seseorang menerima gadai. Hal ini terbukti bahwa dari sekian responden yang diwawancarai hanya satu yang mengaku rela menggadai sawah (khusus untuk sawah saudaranya) dengan tidak mengambil manfaat dari sawah yang digadaikan padanya. Walaupun ada beberapa responden yang mengaku terdorong menggadai sawah karena sekedar menolong kerabat dekatnya namun tetap tidak rela (merasa rugi) jika tidak memperoleh hasil dari sawah yang ditahannya.

Kasus praktek gadai yang terjadi di Kecamatan Gunung Tuleh ada beberapa bentuk, diantaranya:

Pertama, Bapak Isnardi sebagai pihak penggadai

Isi perjanjian gadai menjelaskan bahwa Bapak Isnardi disebut sebagai pihak I (pertama) atau penggadai, umur 52 tahun, dan pekerjaan wiraswasta. Kemudian, Bapak Deddi (lima puluh juta rupiah) kepada pihak II atau penerima gadai dengan menyerahkan lahan sawit seluas 2 ha (hektar) dalam jangka waktu 2 tahun pada tanggal 12 Mei 2015.

Seluruh pengelolaan dan penggunaan lahan sawit menjadi hak dan tanggung jawab penerima gadai sampai pinjaman lunas. Apabila pinjaman tersebut belum dilunasi oleh penggadai, maka akan diberi tenggang waktu selama 2 bulan. Dan apabila penggadai tidak bisa melunasi utangnya sampai batas waktu yang diperjanjikan maka penggadai harus membayar biaya tambahan sebesar Rp. 200.000,- setiap bulan atau sekitar 0,4\% dari jumlah pinjaman.

Berdasarkan hasil wawancara dengan Bapak Isnardi selaku penggadai menjelaskan bahwa dia menggadaikan lahan sawitnya kepada Bapak Deddi Yandra, kata-kata yang diucapkan Bapak Isnardi selaku penggadai adalah "Bang, porlu jau epeng untuk mambangun bagas. Tiop abang ma lahan sawit kon 2 (dua) hektar, au pinjam epeng abang lima pulu juta salambat 2 (dua) taon 
mulai mon tanggal $12 \mathrm{Mei} 2015 \mathrm{na}$ on". Kemudian Bapak Deddi Yandra menjawab, "ulehen ma diho epeng nagiot mi, tai ho harus malunasi sampai waktu parjanjian nai, pala inda lunas ho harus membayar bunga dua ratus ribu satiop bulan". Maksudnya, (Bang, saya perlu uang untuk membangun rumah. Abang pegang lahan sawit saya ini 2 (dua) hektar, dan saya pinjam uang abang sebesar Rp. 50.000.000,- selama 2 (dua) tahun dari tanggal 12 Mei 2015. Kemudian Bapak Deddi Yandra menjawab, saya berikan uang yang kamu inginkan, tapi kamu harus melunasi sesuai waktu perjanjian. Kalau tidak bisa dilunasi maka harus membayar bunga sebesar Rp. 200.000,- setiap bulannya.

Pada tanggal 20 Maret 2016 Bapak Isnardi sudah menebus sebagian utangnya kepada Bapak Deddi Yandra dengan jumlah keseluruhannya sebesar Rp. 20.000.000,-. Sesuai dalam surat perjanjian, apabila penggadai (rahin) tidak bisa melunasi utangnya sampai batas waktu yang ditentukan maka akan dibebankan biaya tambahan sebesar Rp. 200.000,- (dua ratus ribu rupiah) setiap bulan. Karena Bapak Isnardi tidak bisa melunasi utangnya sesuai batas tenggang waktu yang diberikan dalam surat perjanjian maka sejak tanggal 13 Juli 2017 Bapak
Isnardi harus membayar biaya tambahan atau bunga sebesar Rp. 200.000,- (dua ratus ribu rupiah) atau sekitar $0,4 \%$ dari jumlah pinjaman setiap bulannya.

Berdasarkan hasil wawancara peneliti dengan Bapak Isnardi selaku penggadai (rahin), ia sering didatangi oleh Bapak Deddi Yandra untuk segera melunasi utangnya beserta dengan biaya tambahan yang diperjanjikan, hampir setiap sekali seminggu bapak Deddi Yandra datang kerumahnya. Bapak Isnardi sudah menebus biaya tambahannya sebanyak 3 (tiga) kali, kalau dijumlahkan menjadi Rp. 600.00o,-. Jadi, jumlah seluruh utang yang sudah dibayar Bapak Isnardi adalah sebesar Rp. 20.600.000,- (dua puluh juta enam ratus ribu rupiah). (Isnardi, Penggadai, Wawancara, tanggal o5 Juli 2018)

Bapak Deddi Yandra juga mengatakan bahwa adanya tambahan terhadap jumlah pinjaman tersebut, agar mendapatkan sedikit keuntungan. Karena akhir-akhir ini hasil dari panen semakin menurun dan harga sawit sekarang lebih murah daripada sebelumnya. (Deddi Yandra, Penerima Gadai, Wawancara, o7 Juli 2018).

Berdasarkan wawancara dengan Bapak Arqam selaku Kepala Jorong Paraman Ampalu, terkait dengan 
kasus di atas mengatakan bahwa praktek gadai di atas tidak masalah untuk dilaksanakan karena sudah menjadi kebiasaan di lingkungan masyarakat dan bukan sesuatu hal yang baru. Sehingga penggadai (rahin) bisa mendapatkan uang secepatnya tanpa harus bertele-tele pergi ke suatu bank. (Arqam, Kepala Jorong Paraman Ampalu Wawancara, 8 Juli 2018).

Bapak Rafki selaku ahli waris tidak mengetahui bahwa Bapak Isnardi selaku penggadai telah menggadaikan lahan sawitnya kepada Bapak Deddi Yandra. (Rafki, Ahli Waris, Wawancara, o8 Juli 2018).

Sesuai dengan hasil wawancara dengan saksi, yaitu Bapak Abdul Hafis mengatakan bahwa dalam perjanjian gadai tersebut tidak ada ahli waris yang ikut serta menandatangani perjanjian gadai bahkan ahli waris tidak ada yang mengetahui seorangpun. (Abdul Hafis, Saksi, Wawancara, 8 Juli 2018).

Pendapat penulis sesuai dengan kasus praktek gadai di atas, bahwa seluruh pengelolaan dan hasil dari lahan sawit tersebut dikuasai oleh penerima gadai (murtahin) dan adanya biaya tambahan yang harus diberikan oleh penggadai (rahin) kepada penerima gadai (murtahin) apabila utang tidak bisa ditebus sesuai jangka waktu yang ditetapkan dalam akad, yaitu penggadai harus membayar biaya tambahan sebanyak Rp. 200.000,- atau 0,4\% dari Rp. 50.000.000,- setiap bulan.

Kedua, Bapak Epa sebagai pihak penggadai

Isi perjanjian gadai menjelaskan bahwa Bapak Epa disebut sebagai pihak I (pertama) atau penggadai, umur 46 tahun, dan pekerjaan sebagai petani. Kemudian, Bapak Akmam disebut sebagai pihak II (kedua) atau penerima gadai, umur 53 tahun, dan pekerjaan sebagai wiraswasta. Dalam isi perjanjian menyatakan bahwa pihak I (pertama) atau penggadai telah meminjam uang sebanyak Rp. 40.000.000,- kepada pihak II (kedua) atau penerima gadai dengan menyerahkan lahan sawitnya dengan luas 1 ha (hektar) selama 1 tahun sejak tanggal 20 Agusutus 2015. Dengan persyaratan apabila uang sudah dikembalikan maka harus membayar biaya tambahan sebanyak Rp. 5.000.000,-.

Hasil wawancara dengan Bapak Epa sebagai penggadai datang ke rumah Bapak Akmam, adapun percakapan yang terjadi adalah: "kahannggi, porlu jau epeng 40 juta. Tiop kahanggi ma lahan sawit ki na di ranto panjang i saluas sada hektar salamo dua taon mon tanggal 20 Agustus 2015 on. Kemudian Bapak Aswar menjawab, "olo, inda manguai 
tai harus adong epeng tambahna lima juta pala dung dipaulakko utang mi”. Maksudnya, (Bang, saya perlu uang sebesar Rp. 40.000.000,-, abang pegang lahan sawit yang ada di ranto panjang seluas 1 ha (hektar) selama 2 (dua) tahun sejak tanggal 20 Agustus 2015. Kemudian Bapak Aswar menjawab, "Ya, tidak apa-apa tapi harus ada uang tambahannya sebesar Rp. 5.000.000,- waktu penebusan utang". (Epa, Wawancara, tanggal 12 Juli 2018). Dengan isi perjanjian seluruh pengelolan dan hasil lahan sawit tersebut menjadi hak pihak penerima gadai dan setelah sampai dua tahun penggadai menebus kembali lahan sawitnya dengan persyaratan harus membayar biaya tambahan atau bunga sebanyak Rp. 5.000.000,-. Jadi, apabila dijumlahkan uang yang harus ditebus oleh Bapak Epa sebesar Rp. 45.000.000,-. Sampai saat sekarang ini belum ada uang yang ditebus oleh Bapak Epa kepada Bapak Akmam, sehingga lahan sawit tersebut masih berada dalam penguasaan Bapak Akmam selaku penerima gadai.

Bapak Akmam selaku penerima gadai (murtahin) mengatakan bahwa tujuan dari praktek gadai tersebut ialah untuk membantu penggadai (rahin) mendapatkan uang yang diinginkannya, sekaligus untuk bisnis dan mendapatkan keuntungan yang sebesar-besarnya. (Akmam, Penerima Gadai, Wawancara, 13 Juli 2018).

Pendapat penulis sesuai dengan kasus praktek gadai di atas adalah seluruh pengelolaan dan hasil dari lahan sawit tersebut dikuasai oleh penerima gadai (murtahin) dan adanya biaya tambahan yang harus diberikan oleh penggadai (rahin) sebesar Rp. 5.000.000,- pada saat penebusan utang yang diperjanjikan dalam akad.

Ketiga, Bapak Thamrin Nasution sebagai pihak penggadai

Isi perjanjian menjelaskan bahwa Bapak Thamrin Nasution disebut sebagai pihak I (pertama) atau penggadai, umur 59 tahun dan pekerjaan sebagai wiraswasta. Kemudian, Bapak Indriadi disebut sebagai pihak II (kedua) atau penerima gadai, umur 42 tahun dan pekerjaan sebagai petani. Dalam isi perjanjian menyatakan bahwa pihak I (pertama) atau penggadai mengaku telah meminjam uang sebesar Rp. 65.000.000,- kepada pihak II (kedua) atau penerima gadai dengan menyerahkan lahan sawit dengan luas 3 ha (hektar) sejak tanggal o6 Juli 2015.

Seluruh hak pengelolaan lahan sawit tersebut menjadi hak penerima gadai sampai pinjaman lunas. Apabila pinjaman tersebut belum dilunasi oleh penggadai maka akan diberi tenggang 
waktu selama 1 bulan. Dan apabila pihak pertama tidak bisa melunasi sampai batas waktu yang diperjanjikan maka lahan sawit tersebut secara otomatis menjadi hak milik penerima gadai.

Hasil wawancara dengan Bapak Thamrin Nasution selaku penggadai menjelaskan bahwa dia menggadaikan lahan sawitnya kepada Bapak Indriadi selaku penerima gadai dengan luas lahan sawit 3 ha (hektar). Bapak Thamrin Nasution datang ke rumah Bapak Indriadi untuk menggadaikan lahan sawitnya dan ia mengatakan, "Udak, au giot manggadaeon lahan ni sawit kon tu udak sabahat tolu hektar harana porlu jau epeng onom pulu lima juta untuk modal usaho tobat gulaen dot biaya anak kuliah. Pala bisa garina mon tanggal o6 Juli 2015 na onma". Kemudian Bapak Indriadi menjawab, "inda manguai, tapi harus adong syaratna, parjanjian on salambat sataon lalu lahan sawit on hasil nai jau sampe utangmu lunas, pala inda lunas sasuai waktu nai jau lahan sawit mon". Maksudnya (Pak, saya mau menggadaikan lahan sawit sebanyak 3 ha (hektar) karena saya perlu uang sebesar Rp. 65.000.000,- untuk modal usaha kolam ikan dan biaya anak kuliah. Kalau bisa terhitung sejak tanggal o6 Juli 2015. (Thamrin Nasution, Wawancara, tanggal 14 Juli
2018). Kemudian Bapak Indriadi mengatakan, tidak apa-apa, tapi harus ada syaratnya yaitu perjanjian ini selama 1 (satu) tahun, seluruh pengelolaan hasil lahan sawit diserahkan kepada saya dan apabila tidak lunas, maka lahan sawit menjadi milik saya). (Bapak Indriadi, Wawancara, tanggal 16 Juli 2018).

Selanjutnya, di dalam perjanjian disebutkan bahwa masa waktu penebusan utang gadai dari tanggal 06 Juli 2015 sampai tanggal o6 Juli 2016 dengan masa tenggang waktu 1 (satu) bulan. Pada tanggal 10 Januari 2016 Bapak Thamrin Nasution sudah menebus sebagian utangnya kepada Bapak Indriadi sebesar Rp. 25.000.000,- (dua puluh lima juta rupiah). Namun, Bapak Thamrin Nasution tidak bisa melunasi utangnya sampai batas waktu perjanjian, dan pada akhirnya lahan sawit tersebut menjadi milik Bapak Indriadi terhitung sejak tanggal o6 Agustus 2016.

Pendapat penulis sesuai dengan praktek gadai di atas, bahwa apabila penggadai (rahin) tidak bisa menebus utang gadai sesuai dengan jangka waktu yang ditetapkan dalam akad, maka kepemilikan lahan sawit tersebut menjadi milik penerima gadai (murtahin).

Keempat, Suparman sebagai pihak penggadai 
Isi perjanjian menjelaskan bahwa Bapak Suparman disebut sebagai pihak I (pertama) atau penggadai, umur 54 tahun, dan pekerjaan sebagai petani. Kemudian, Bapak Hasan Basri disebut sebagai pihak II (kedua) atau penerima gadai, umur 56 tahun, dan pekerjaan sebagai petani. Dalam isi perjanjian menyatakan bahwa pihak I (pertama) atau penggadai telah meminjam uang sebesar Rp. 27.000.000,- kepada pihak II (kedua) atau penerima gadai dengan menyerahkan lahan sawit seluas 4 hektar sejak tanggal 23 Desember 2014 tanpa disebut secara jelas jangka waktunya. Namun, dalam perjanjian disebutkan bahwa penerima gadai harus mengembalikan lahan sawitnya kepada penggadai setelah pinjaman lunas.

Berdasarkan hasil wawancara dengan Bapak Suparman sebagai pihak penggadai yang menggadaikan lahan sawitnya kepada Bapak Hasan Basri, "Lae, au giot manggadeon lahan sawit kon tuho 4 hektar, harana giot maminjam epeng au jo dua pulu pitu juta ken biaya ni pernikahan anakku mulai mon 23 Desember 2014 on ma". Kemudian Bapak Hasan Basri menjawab, "au lehen pe diho sajia giotmu". Maksudnya, (Abang Ipar, saya ingin menggadaikan lahan sawit kepada abang seluas 4 ha (hektar), karena saya mau meminjam uang sebesar Rp. 27.000.000,- untuk biaya pernikahan anak saya dari tanggal 23 Desember 2014. Kemudian Bapak Hasan Basri menjawab, saya berikan uang sesuai yang kamu inginkan). (Suparman, Penggadai, Wawancara, tanggal 18 Juli 2018).

Pada tanggal 5 Mei 2017 Bapak Hasan Basri selaku penerima gadai (murtahin) telah menjual lahan sawit milik Bapak Suparman seluas 4 ha (hektar) tersebut kepada Bapak Rajuddin dengan jumlah harga sebesar Rp. 50.000.000,- (lima puluh juta rupiah) tanpa sepengetahuan Bapak Suparman selaku penerima gadai (murtahin) yang sebelumnya masih dalam ikatan perjanjian gadai. (Hasan Basri, Penerima Gadai, Wawancara, 20 Juli 2018). Kemudian, uang yang diterima dari penjualan lahan sawit tersebut digunakan untuk melunasi utang Bapak Suparman, namun sisa uang yang diterima Bapak Hasan Basri dalam penjualan lahan sawit tersebut tidak diberikan kepada Bapak Suparman tetapi digunakan untuk konsumsi sendiri. (Suparman, Penggadai, Wawancara, tanggal 18 Juli 2018).

Bapak Suparman selaku penggadai (rahin) tidak mengetahui bahwa lahan sawit miliknya sudah dijual oleh Bapak Hasan Basri selaku 
penerima gadai (murtahin) kepada Bapak Rajuddin. Bapak Suparman mengatakan bahwa dia sudah menebus sebagian utangnya sebesar Rp. 7.000.000,- (tujuh juta rupiah) kepada Bapak Hasan Basri. (Suparman, Penggadai, Wawancara, 20 Juli 2018).

Pendapat penulis sesuai dengan kasus praktek gadai di atas, bahwa seluruh pengelolaan dan hasil lahan sawit tersebut dikuasai oleh penerima gadai (murtahin) dan penggadai (rahin) tidak mengetahui bahwa penerima gadai (murtahin) telah menjual lahan sawit miliknya kepada orang lain atau pihak ketiga. Kemudian, sisa uang dari hasil dari penjualan lahan sawit tersebut tidak diberikan kepada penggadai (rahin) selaku pemilik sah dari lahan sawit tersebut.

Kelima, Bapak Marta sebagai pihak penggadai

Isi perjanjian gadai menjelaskan bahwa Marta disebut sebagai pihak I (pertama) atau penggadai, umur 42 tahun, dan pekerjaan sebagai petani. Kemudian, Bapak Zulkani disebut sebagai pihak II (kedua) atau penerima gadai, umur 38 tahun, dan pekerjaan sebagai petani. Dalam isi perjanjian menyatakan bahwa pihak I (pertama) atau penggadai telah meminjam uang sebesar Rp. 30.000.000,- kepada pihak II (kedua) atau penerima gadai dengan syarat penggadai harus menyerahkan lahan sawitnya seluas 1 ha (hektar) kepada pihak penerima gadai selama 10 tahun. Segala hasil panen dan biaya perawatan lahan sawit menjadi hak dan tanggung jawab pihak penerima gadai. Selanjutnya, setelah jangka waktu 10 tahun hutang pihak penggadai kepada penerima gadai dianggap lunas dan lahan sawit tersebut dikembalikan kepada pihak penggadai.

Hasil wawancara dengan Bapak Marta sebagai pihak penggadai yang menggadaikan lahan sawitnya kepada Bapak Zulkani, "ayah tuo, au gadeon kon lahan sawit di mamak saluas sada hektar, harana giot maminjam epeng au tu mamak tolu pulu juta. Epeng nai parguna kan parubat ni alak bagas, pala bisa garina mon tanggal 21 Juni 2014 na onma. Maksudnya, (Pak, saya menggadaikan lahan sawit kepada bapak seluas 1 ha (hektar), karena saya mau meminjam uang sama bapak Rp. 30.000.000,-Uangnya digunakan untuk berobat istri, kalau bisa dari tanggal 21 Juni 2014). (Marta, Penggadai, Wawancara, 25 Juli 2018). Seluruh pengelolaan dan hasil lahan sawit menjadi milik Bapak Zulkani sampai sepuluh tahun, namun apabila dihitung 3 (tiga) tahun saja hasil dari lahan sawit tersebut sudah bisa 
melunasi utang dari Bapak Zulkani, karena sesuai dengan wawancara dengan Bapak Zulkani 1 (satu) bulan saja sudah ada 2 juta uang yang diterima dari lahan sawit tersebut. (Zulkani, Penerima Gadai, Wawancara, 27 Juli 2018).

Pendapat penulis sesuai dengan kasus praktek gadai di atas, bahwa seluruh pengelolaan dan hasil dari lahan sawit tersebut dikuasai oleh penerima gadai (murtahin) selama 10 tahun. Setelah jangka waktu tersebut utang penggadai (rahin) dianggap sudah lunas dan penerima gadai harus mengembalikan lahan sawit tersebut kepada penggadai.

B. Analisis Hukum Ekonomi Syariah terhadap Praktek Gadai Lahan Sawit di Kecamatan Gunung Tuleh Kabupaten Pasaman Barat.

Bentuk-bentuk praktek gadai yang ada di Kecamatan Gunung Tuleh Kabupaten Pasaman Barat yang terjadi antara pihak penggadai (rahin) dan pihak penerima gadai (murtahin) dilakukan atas dasar suka sama suka. Penggadai (rahin) serta penerima gadai (murtahin) sudah memenuhi rukun yaitu penggadai (rahin), penerima gadai (murtahin), barang gadai (marhun), dan adanya utang (marhun bih). Namun syarat-syarat gadai belum terpenuhi yaitu shigat akad dimana dalam praktek gadai tersebut masih digantungkan dengan syarat yaitu adanya pemanfaatan barang gadai oleh penerima gadai dan adanya tambahan biaya dalam penebusan utang. Sementara dalam hukum ekonomi syariah disebutkan bahwa apabila akad gadai digantungkan dengan syarat atau disandarkan kepada masa yang akan datang, maka akad fasid seperti halnya jual beli. Syafi'iyah dan Hanafiyah berpendapat bahwa syarat gadai sama dengan syarat jual beli, karena gadai merupakan akad maliyah. Salah satu ulama mazhab Hanafi yaitu Syeikh Alauddin AlSamarqandy dalam Tuhfatu alFuqaha' Li Al-Samarqandy menjelaskan:

"Karena sesungguhnya penetapan syarat kemanfaatan bagi salah satu pihak yang bertransaksi adalah termasuk pasal riba atau merupakan bagian dari syubhatnya riba". (Al-Samarqandy, 1984: 52)

Barang gadai yang dijadikan objek oleh masyarakat Kecamatan Gunung Tuleh Kabupaten Pasaman Barat adalah lahan sawit yang sudah memenuhi rukun dan syarat yaitu barang yang bernilai harta, jelas kepemilikan barang, barang yang diakadkan ada ketika transaksi berlangsung dan diterima oleh pihak penerima gadai. 
Kasus-kasus praktek gadai yang terjadi pada masyarakat Kecamatan Gunung Tuleh Kabupaten Pasaman Barat terdapat beberapa permasalahan diantaranya adalah:

1. Pemanfaatan Barang Gadai

Pemanfaatan barang gadai yang dilakukan oleh masyarakat Kecamatan Gunung Tuleh Kabupaten Pasaman Barat, dimana barang gadai dimanfaatkan oleh penerima gadai (murtahin) selama barang gadai belum ditebus atau dibayar utangnya oleh si penggadai (rahin), padahal dalam konsep hukum ekonomi syariah atau fikih muamalah bahwa barang gadai tidak boleh dimanfaatkan oleh penerima gadai (murtahin. Dengan demikian, orang yang memberikan hutang tidak diperbolehkan mengambil manfaat dari barang yang digadaikan, meskipun orang yang berutang mengizinkannya. Apabila dia mengambil manfaat dari barang yang digadaikan, maka ia adalah piutang yang mendatangkan manfaat dan setiap piutang yang mendatangkan manfaat adalah riba. (Sayyid Sabiq, 2009: 46)

Jumhur Fuqaha berpendapat bahwa penerima gadai (murtahin) tidak boleh mengambil suatu manfaat barang-barang gadaian tersebut, sekalipun penggadai (rahin) mengizinkannya, karena hal termasuk kepada utang yang mendatangkan manfaat, sehingga bila dimanfaatkan termasuk riba, Sebagaimana kaidah fiqh yang menyatakan:

Setiap piutang yang ditarik manfaat di dalamnya, maka itu adalah riba. (Al-Ats Qalani, 1993: 56)

Gadai diperbolehkan di dalam Islam karena mengandung unsur tolong-menolong dan perbuatan tersebut sangat dianjurkan di dalam Islam. Sebagaimana firman Allah dalam surat Al-Maidah ayat 2 yang berbunyi:

"Dan tolong-menolonglah kamu dalam (mengerjakan) kebajikan dan takwa, dan jangan tolongmenolong dalam berbuat dosa dan pelanggaran. dan bertakwalah kamu kepada Allah, Sesungguhnya Allah amat berat siksa-Nya”. (QS. Al-Maidah: 2)

Bentuk praktek gadai yang terjadi di Kecamatan Gunung Tuleh Kabupaten Pasaman Barat, dapat penulis ambil kesimpulan berdasarkan hasil wawancara yang penulis lakukan bahwa pihak penggadai menggadaikan lahan sawitnya melampaui batas waktu sebagaimana yang telah dijelaskan di dalam perjanjian yang umumnya menggunakan akad gadai dimana 
utang harus dilunasi sesuai waktu yang diperjanjikan. Realita yang terjadi pihak penggadai belum juga menebus lahan sawit miliknya hingga belasan tahun lamanya. Padahal di dalam Al-Qur'an dijelaskan tentang kewajiban untuk menjalankan akad atau perjanjian sebagaimana dijelaskan di dalam surat Al-Maidah ayat 1 yang berbunyi:

“.....Hai orang-orang yang

beriman, penuhilah aqad-aqad itu...”. (QS. Al-Maidah: 1)

Berdasarkan penjelasan ayat di atas, telah dijelaskan untuk memenuhi akad-akad atau perjanjian dalam suatu muamalah. Sama halnya dengan praktek gadai yang terjadi di Kecamatan Gunung Tuleh Kabupaten Pasaman Barat dalam hal ini khususnya kepada pihak penggadai (rahin) agar memenuhi atau melaksanakan isi akad untuk menebus kembali lahan sawitnya setelah waktu gadai berakhir. Sehingga akad atau perjanjian yang telah dibuat dan disetujui oleh kedua belah pihak dapat terlaksana sesuai dengan isi perjanjian tersebut.

Selain masalah penebusan utang yang tidak sesuai dengan perjanjian, hukum ekonomi syariah juga memandang permasalahan tentang pemanfaatan gadai lahan sawit yang dilakukan oleh penerima gadai di Kecamatan Gunung Tuleh. Karena dalam hukum ekonomi syariah pada dasarnya barang gadai tidak boleh diambil manfaatnya oleh penerima gadai, namun tetap menjadi hak milik penggadai. Kecuali apabila telah mendapat izin dari masing-masing pihak yang bersangkutan untuk menghindari kemubaziran. Sebab hak pemilik barang tidak memiliki secara sempurna yang memungkinkan melakukan perbuatan hukum, misalnya mewakafkan, menjual dan sebagainya sewaktu-waktu atas barang miliknya itu. Sedangkan hak penerima gadai terhadap barang gadai hanya ada pada keadaan atau sifat kebendaannya yang mempunyai nilai, tetapi tidak pada guna dan pemanfaatan/pengambilan hasilnya. Seperti hadis Rasulullah Saw yang diriwayatkan oleh Bukhari:

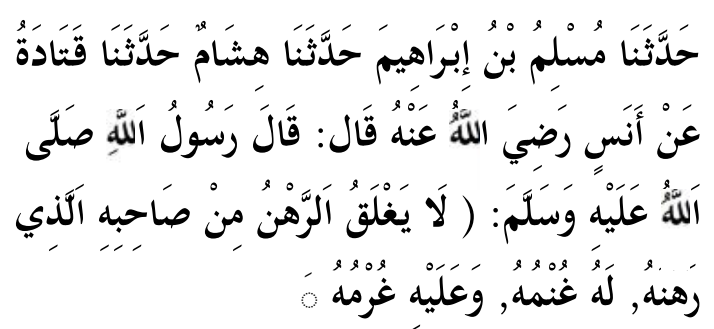

"Telah menceritakan kepada kami Muslim bin Ibrahim telah menceritakan kepada kami Hisyam telah menceritakan kepada kami Qatadah dari Anas radliallahu 'anhu berkata: Rasulullah bersabda "Tidak terlepas kepemilikan barang gadai dari pemilik yang 
menggadaikannya. Ia memperoleh manfaat dan menanggung resikonya." (Bukhari, 1996: 231)

Penerima gadai (rahin) hanya berhak menahan barang gadai, tetapi tidak berhak menggunakan atau memanfaatkan/mengambil hasilnya. Sementara itu, pemilik barang gadai berhak menggunakan barang tersebut, baik untuk mengelolanya maupun mendapatkan hasil dari barang gadai tersebut. (Karim, 2010: 13)

Menurut hukum Islam, jika yang menggunakan barang gadaian itu adalah orang yang menerima gadai, terdapat tiga keadaan: Pertama, jika penerima gadai (murtahin) menggunakan barang gadaian tersebut tanpa imbalan standar, maka hal itu diharamkan karena termasuk dalam kategori riba. Berkata Ibnu Qudamah:

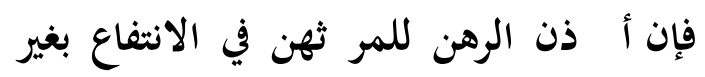

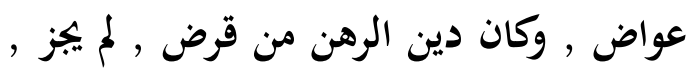

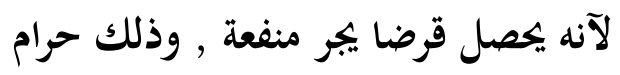

"Jika rahin (pemilik barang gadai) mengizinkan bagi murtahin (pemegang gadai) untuk memanfaatkan barang gadai tersebut tanpa ada imbalan, sedang rahin berhutang kepada murtahin, maka hal ini tidak boleh, karena utang yang memberikan manfaat bagi yang memberikan utang, sehingga masuk dalam kategori riba". (Qudamah, 1997: 431)

Kedua, jika murtahin memanfaatkan barang gadai tadi dengan imbalan yang standar, maka para ulama berbeda pendapat: mayoritas ulama tidak membolehkannya, sedangkan Mazhab Hanabilah membolehkannya, karena yang demikian itu masuk dalam kategori akad sewa, dan bukan termasuk memanfaatkan barang gadaian. Ini adalah sebagian pendapat ulama Hanabilah, tetapi mayoritas ulama tidak membolehkannya karena barang gadaian tersebut bukan milik pemegang gadai. (Rusyd, 2010: 276).

Ketiga, jika barang gadai tersebut membutuhkan biaya perawatan, maka biayanya ditanggung oleh rahin (pemilik gadai tersebut). Jika penggadai tidak memberikan biaya perawatan, maka penerima gadai yang mengeluarkan biaya perawatan, tetapi dia dibolehkan untuk memanfaatkannya sesuai dengan biaya yang dikeluarkannya. Dalilnya adalah hadis yang diriwayatkan oleh Bukhari, bahwasanya Rasulullah Saw bersabda:

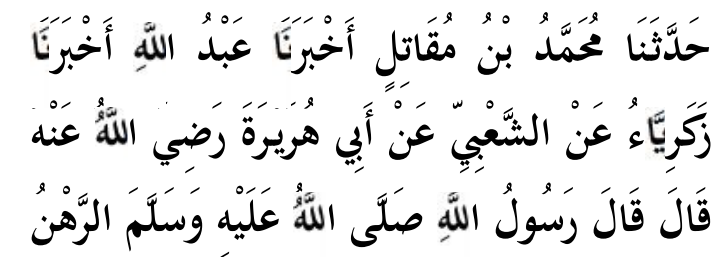




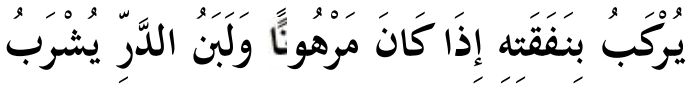

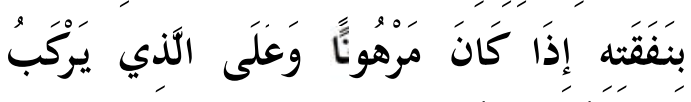
وَيَشْرَبُ النَّفَقَة

"Telah menceritakan kepada kami Muhammad bin Muqatil telah mengabarkan kepada kami 'Abdullah telah mengabarkan kepada kami Zakariya' dari AsySya'biy dari Abu Hurairah radliallahu 'anhu berkata; Rasulullah shallallahu 'alaihi wasallam bersabda: (Hewan) boleh dikendarai jika digadaikan dengan pembayaran tertentu, susu hewan juga boleh diminum bila digadaikan dengan pembayaran tertentu, dan terhadap orang yang mengendarai dan meminum susunya wajib membayar." (H.R Bukhari) (Bukhari, 1996: 161).

Adapun hadis di atas dianggap mansukh dengan hadis Ibnu Umar yang menyatakan bahwa tidak dibolehkan memerah susu kambing orang lain, kecuali dengan izinnya. Bahkan Imam Mawardi menyatakan bahwa hadis di atas tidak ada katakata yang menerangkan bahwa yang menaiki dan memanfaatkan barang gadaian tersebut adalah pemegang gadai (murtahin). Berkata Imam Mawardi: "Dalam hadis di atas diterangkan bahwa biaya perawatan dibebankan kepada yang menaiki dan meminum susunya, padahal kewajiban perawatan dibebankan kepada rahin (yang menggadaikan) bukan kepada murtahin (yang menerima gadai)". (Mawardi, t.th: 14). Hal senada juga disampaikan oleh Ibnu Rusyd di dalam Bidayat alMujtahid: "Tidak benar kalau diartikan bahwa yang menaiki dan yang memerah susunya adalah pemegang gadai (murtahin). (Rusyd, 2010: 276).

Seharusnya diusahakan agar didalam perjanjian gadai itu tercantum jika pemegang gadai minta diizinkan memanfaatkan barang gadai, maka hasilnya menjadi milik bersama (production sharing). Ketentuan ini dimaksudkan untuk menghindari harta benda tidak berfungsi (mubazir). (Salim, 2012: 5).

Dari pembahasan di atas, bisa kita simpulkan bahwa pemegang gadai tidak boleh memanfaatkan barang gadaian seperti lahan sawit, sawah, sepeda motor dan lain sebagainya, dalam bentuk apapun juga walaupun sudah diizinkan pemiliknya. Karena hal itu termasuk riba yang diharamkan dalam Islam. Kecuali jika barang gadaian tersebut perlu biaya perawatan sedang pemiliknya tidak mau mengeluarkan biaya perawatan, sehingga biayanya dibebankan kepada pemegang gadai dan di dalam perjanjian harus tercantum bahwa 
pemegang gadai boleh memanfaatkan barang gadai kemudian hasilnya menjadi milik bersama (production sharing) untuk menghindari harta benda tidak berfungsi (mubazir). Dalam keadaan seperti ini menurut sebagian kecil ulama, diperbolehkan pemegang memanfaatkan barang gadaian tersebut sebesar biaya perawatan yang dikeluarkan.

Mayoritas ulama tetap mengharamkannya secara mutlak. Hal yang serupa pernah ditanyakan oleh para ulama yang terkumpul dalam Lajnah Daimah untuk fatwa di Arab Saudi dan mereka menyatakan bahwa hukumnya haram, karena termasuk dalam kategori riba. Ulama Mazhab Hanafi, Mazhab Maliki, dan ulama Mazhab Syafi'i berpendapat sekalipun pemilik barang itu mengizinkannya, pemegang agunan tidak boleh memanfaatkan barangnya. Karena apabila barang gadaian itu dimanfaatkan, maka hasil pemanfaatan tersebut merupakan riba yang dilarang syara' sekalipun memperoleh izin dari pemiliknya. Bahkan menurut pernyataan tersebut rela dan izin dalam hal ini lebih cenderung dalam keadaan terpaksa, karena tidak akan mendapatkan uang yang akan dipinjam itu bila tidak diizinkan. Selain itu, dalam masalah riba menurut mereka, rela dan izin tidak ada pengaruh dan tidak berlaku. (Salim, 2012: 7)

Jika dilihat dari bentuk-bentuk praktek gadai yang terjadi di Kecamatan Gunung Tuleh Kabupaten Pasaman Barat, lahan sawit yang digadaikan dipakai dan dimanfaatkan sepenuhnya oleh pihak penerima gadai, hal ini bertentangan sudah jelas bertentangan dengan syariat Islam. Hasil dari pemanfaatan lahan sawit yang digadaikan tersebut di dalam Islam merupakan harta riba, karena jumlah yang diterima oleh pemberi gadai akan bertambah dengan hasil yang diperoleh dari lahan sawit yang digadaikan tersebut. Semua harus dikembalikan pada prinsip gadai sebagai akad tabarru', akad yang motifnya murni untuk membantu bukan mendapatkan keuntungan.

Idealnya bentuk praktek gadai lahan sawit di Kecamatan Gunung Tuleh Kabupaten Pasaman Barat sudah seharusnya memuat unsur syariat khususnya hukum ekonomi syariah. Namun, pada pada prakteknya masih menyimpang dari apa yang diharapkan, karena praktek tersebut sudah menjadi kebiasaan turun temurun.

Jalan tengah yang mungkin dapat dipakai adalah bahwa praktek gadai lahan sawit di Kecamatan Gunung Tuleh Kabupaten Pasaman Barat tidak lagi membolehkan penerima gadai 
(murtahin) untuk mengambil manfaat dari lahan sawit tersebut, melainkan hanya dengan memegang surat-surat tanah/sertfikat tanah disertai dengan perjanjian gadai.

2. Adanya biaya tambahan

Adanya tambahan uang pengembalian dalam praktek gadai lahan sawit di Kecamatan Gunung Tuleh Kabupaten Pasaman Barat sesuai dengan hasil wawancara yang penulis lakukan dengan pihak yang menjalankan praktek gadai lahan sawit, bahwasanya operasional praktek gadai lahan sawit ini dilatarbelakangi oleh bisnis atau memang benar-benar diniati untuk bisnis yang memberikan keuntungan yang sangat menjanjikan.

Kasus pertama dilakukan oleh Bapak Deddi Yandra yang menerapkan tambahan uang sebesar 0,4\% dari Rp. 50.000.000,- yaitu Rp. 200.000,- setiap bulan apabila Bapak Isnardi tidak bisa menebus utangnya kembali sesuai dengan batas waktu yang diperjanjikan terhitung setelah melewati batas akhir perjanjian tersebut yang telah diperjanjikan diawal akad. Dimana sebagai jaminan berupa lahan sawit seluas 2 ha (hektar). Namun, Bapak Isnardi tidak bisa melunasi utangnya, pada akhirnya dia diharuskan membayar biaya tambahan sebesar Rp. 200.000,-/bulan. Kemudian, Bapak
Isnardi selaku penggadai sudah membayar sebagian utangnya sebesar Rp. 20.000.000,- serta biaya tambahannya sebanyak 3 (tiga) bulan yaitu Rp. 600.000,- bila dijumlahkan uang sudah ditebus sebesar Rp. 20.600.000,-

Kasus kedua dilakukan oleh Bapak Epa sebagai pihak penggadai yang menggadaikan lahan sawitnya seluas 1 ha (hektar) kepada Bapak Akmam selaku pihak penerima gadai. Penggadai telah meminjam uang sebesar Rp. 40.000.000,- kepada pihak penerima gadai, dimana di dalam isi perjanjian disebutkan apabila lahan sawit tersebut ditebus kembali, maka penggadai diharuskan membayar biaya tambahan sebesar Rp. 5.000.000,-. Jadi, apabila dijumlahkan uang yang harus dibayar oleh Epa adalah sebesar Rp. 45.000.000,-.

Adanya penambahan uang pengembalian dalam transaksi praktek gadai yang dilakukan oleh penerima gadai jelas dikatakan sebagai riba, karena riba itu terjadi ketika harus memberikan tambahan sejumlah uang atau prosentase tertentu yang biasanya ditentukan oleh pihak yang memberi pinjaman dari pokok utang, seperti yang diterapkan oleh Bapak Deddi Yandra dan Bapak Akmam dalam praktek gadainya. Hal seperti itu biasanya 
disebut dengan bunga gadai dan perbuatan tersebut dilarang dalam Islam, karena perjanjian gadai di dalam Islam tidak membenarkan adanya praktek pemungutan bunga sebab akan membebani salah satu pihak, yaitu pihak penggadai. Penggadai akan merasa dianiaya dan tertekan, karena selain harus mengembalikan utangnya dia masih mempunyai kewajiban untuk membayar bunganya. (Sutedi, 2011: 30).

Haramnya riba diperkuat dengan firman Allah surat Al-Baqarah ayat 275 yang berbunyi:

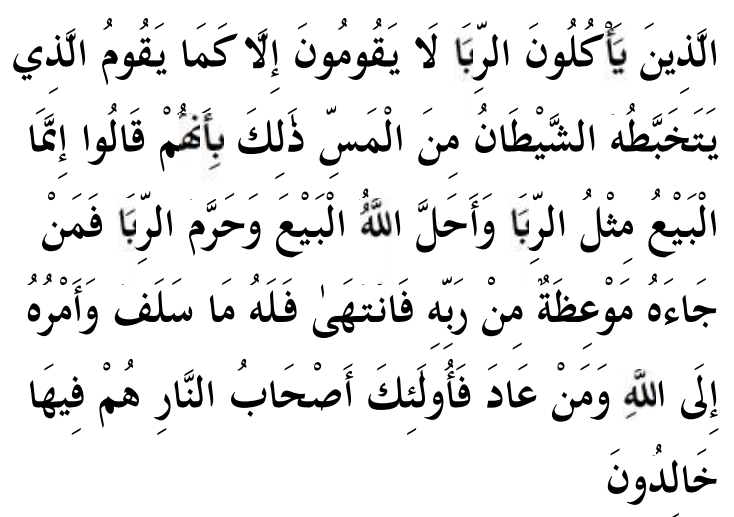

"Orang-orang yang makan (mengambil) riba tidak dapat berdiri melainkan seperti berdirinya orang yang kemasukan syaitan lantaran (tekanan) penyakit gila. Keadaan mereka yang demikian itu, adalah disebabkan mereka berkata (berpendapat), sesungguhnya jual beli itu sama dengan riba, padahal Allah telah menghalalkan jual beli dan mengharamkan riba. Orangorang yang telah sampai kepadanya larangan dari Tuhannya, lalu terus berhenti (dari mengambil riba), maka baginya apa yang telah diambilnya dahulu (sebelum datang larangan); dan urusannya (terserah) kepada Allah. Orang yang kembali (mengambil riba), maka orang itu adalah penghuni-penghuni neraka; mereka kekal di dalamnya." (QS. Al-Baqarah : 275)

Riba yang terdapat dalam gadai ini tergolong riba qardh. Hal ini terlihat dari proses tambahan uang pengembalian, yaitu diawal telah ada kesepakatan bahwa pada kasus pertama apabila tidak bisa melunasi utang sesuai batas waktu perjanjian maka penggadai harus memberikan biaya tambahan atau bunga sebesar Rp. 200.000,- setiap bulan. Jadi, misalnya penggadai tersebut terlambat membayar utangnya selama 5 bulan, maka dia harus membayar biaya tambahan atau bunga selama lima bulan tersebut. Selain itu, pada kasus yang kedua apabila penggadai menebus kembali utangnya maka akan dibebankan biaya tambahan sebesar Rp. 5.000.000,-. Haramnya riba qardh sesuai dengan kaidah fiqh yang berbunyi:

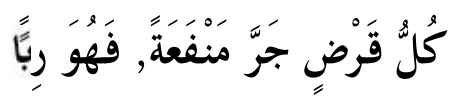


Setiap utang piutang yang ditarik manfaat di dalamnya, maka itu adalah riba. (Al-Ats Qalani, 1993: 56)

Walaupun para pihak saling ridha, namun masih dikategorikan sebagai kezaliman karena adanya tambahan dalam pengembalian utang tersebut didapatkan dari jalur yang tidak dibenarkan oleh Allah SWT. Jika seseorang berutang dan telah masuk masa jatuh tempo belum bisa melunasi utangnya, maka apabila pihak yang memberikan utang memperpanjang waktu pelunasan, seharusnya tidak disertai dengan dengan adanya tambahan uang pengembalian karena penundaan tersebut. Jika pihak yang memberikan utang mengambil tambahan tersebut dan meskipun yang memberikan ridha, tetap saja ia mengambil harta orang lain melalui jalan yang tidak dibenarkan oleh Allah SWT. Ketika pihak yang berutang mengatakan ridha pada hakikatnya pernyataan itu bukanlah suatu keridhaan, karena orang yang berutang tidak dalam kondisi bisa menawar. Jika dia tidak menyanggupi memberikan biaya tambahan, maka ia tidak akan mendapatkan pinjaman uang. Sepertinya ridha tapi sebenarnya bukan ridha.
Dari proses tambahan uang pengembalian tersebut, persis seperti riba yang biasanya dilakukan oleh orang pada zaman Jahiliyah, yaitu pembayaran utang yang ditunda dengan imbalan tambahan bunga, setiap kali terjadi penundaan, maka bunganya bertambah pula, sehingga uang yang semula hanya seratus ribu bisa menjadi beribu-ribu.

Seperti yang telah dijelaskan di atas bahwa adanya tambahan uang pengembalian dalam akad gadai yang dilakukan oleh Bapak Deddi Yandra dan Bapak Akmam termasuk bunga gadai, yang mana bunga gadai itu dilarang dalam Islam karena gadai itu sebagai fungsi sosial (bersifat konsumtif). Artinya, gadai itu untuk kepentingan yang sifatnya mendesak, seperti untuk kepentingan sehari-hari (konsumsi, pendidikan dan kesehatan) yang sangat dibutuhkan oleh masyarakat yang berada dalam golongan berpendapatan menengah ke bawah bukan untuk usah yang sifatnya komersial-produktif.

Hal ini mengingat tujuan awal dari praktek gadai yaitu untuk memberantas lintah darat, rentenir, dan pelaku riba karena pada dasarnya hakikat dan fungsi gadai dalam Islam adalah semata-mata untuk memberikan pertolongan kepada orang yang membutuhkan dengan bentuk marhun (barang) sebagai 
jaminan dan bukan unuk komersial atau usaha dengan mengambil keuntungan sebesar-besarnya tanpa menghiraukan kemampuan orang lain.

Melihat analisis di atas, dapat disimpulkan bahwa bentuk praktek gadai lahan sawit di Kecamatan Gunung Tuleh yaitu adanya uang tambahan dalam pengembalian utang yang dilakukan oleh penerima gadai (murtahin) dilarang oleh agama Islam karena termasuk bunga gadai berjenis riba qardh yang sering dilakukan oleh orang zaman Jahiliyah, karena praktek pemungutan bunga akan membebani salah satu pihak, yaitu pihak penggadai. Penggadai akan merasa dianiaya dan tertekan, karena selain utangnya dia masih mempunyai kewajiban untuk membayar bunganya.

Kemudian, melihat bentuk-bentuk akad praktek gadai lahan sawit yang berlaku dalam masyarakat Kecamatan Gunung Tuleh, maka ditawarkan dua bentuk akad gadai berbasis syariah yang dapat dirumuskan sesuai kebutuhan dan kepentingan penggadai maupun penerima gadai sekaligus untuk mengindari timbulnya kerugian salah satu pihak antara penggadai dan penerima gadai dalam transaksi gadai lahan sawit, maka alternatif yang dapat diambil dalam mekanisme praktek gadai lahan sawit tersebut, yaitu dengan menggunakan dua akad perjanjian gadai. Kedua perjanjian akad tersebut adalah:

a. Akad Qardh al-Hasan

Akad qardh al-hasan adalah suatu akad yang dibuat oleh pihak pemberi gadai dengan pihak penerima gadai dalam hal transaksi gadai harta benda yang bertujuan untuk mendapatkan uang tunai yang diperuntukkan untuk konsumtif yang bersifat daruriy (Ali, 2008: 83), seperti membayar uang sekolah, biaya pengobatan, dan membeli kebutuhan pokok atau primer (beras, lauk pauk, dan lainlain). Dengan demikian, jika penerima gadai mengeluarkan biaya pemeliharaan dan penjagaan atas barang gadai, maka penggadai akan memberikan upah atau fee kepada penerima gadai karena telah menjaga dan merawat lahan sawit tersebut. Jika tidak ada biaya pemeliharaan atau biaya penjagaan, maka penerima gadai tidak dibolehkan mengambil apapun dari penggadai termasuk memanfaatkan lahan sawit yang digadaikan kepadanya. Dengan demikian penggadai tetap berhak menggarap dan memperoleh hasil dari lahan sawitnya sehingga mempercepat proses pelunasan utangnya.

Berkaitan dengan praktek gadai lahan sawit yang terjadi di 
Kecamatan Gunung Tuleh, maka akad qardh al-Hasan ini merurupakan wasilah untuk menolong yang kurang mampu namun memerlukan biaya yang sangat mendesak, maka sebagai alternatif yang dapat diberlakukan baginya adalah memberi pinjaman dengan syarat lahan sawit sebagai jaminan utang untuk menghindari terjadinya penipuan dan kecurangan.

Akad ini pada dasarnya merupakan akad tabarru' yang tidak membebani peminjam namun perlu adanya ketentuan pengembalian pinjaman.

b. Akad mudharabah

Akad mudharabah adalah suatu akad yang dilakukan oleh pihak pemberi gadai (rahin) dengan pihak penerima gadai (murtahin). Dimana pihak pemberi gadai (rahin) atau orang yang menggadaikan harta benda sebagai jaminan untuk menambah modal usahanya atau pembiayaan produktif. Akad dimaksud, pihak pemberi gadai akan memberikan bagi hasil berdasarkan keuntungan yang diperoleh kepada penerima gadai sesuai dengan kesepakatan, sampai modal yang dipinjamnya dilunasi. (Ali, 2008: 85).

Apabila harta benda yang digadaikan itu dapat dimanfaatkan oleh penerima gadai, maka dapat diadakan kesepakatan baru mengenai pemanfaatan harta benda gadaian.

Gadai berdasarkan akad yang dapat disesuaikan dengan jenis harta benda gadaian. Namun, jika pemilik harta benda gadai tidak berniat memanfaatkan harta benda yang dimaksud, penerima gadai dapat mengelola dan mengambil manfaat dari barang itu dan hasilnya diberikan sebagian kepada pihak pemberi gadai berdasarkan kesepakatan. Selain itu, perlu diungkapkan pula bahwa akad mudharabah mempunyai ketentuan yaitu: (Ali, 2008: 102)

1) Jenis barang dalam akad mudharabah dimaksud adalah semua jenis barang yang bisa dimanfaatkan, baik berupa barang bergerak maupun tidak bergerak seperti sepeda motor, barang elektronik, tanah, rumah, maupun jenis barang lainnya yang dapat diambil manfaatnya.

2) Keuntungan yang dibagikan kepada pemilik barang gadai adalah keuntungan sesudah dikurangi biaya pengelolaan.

Akad al-mudharabah dilakukan untuk penggadai (rahin) yang menggadaikan jaminan untuk menambah modal usaha (pembiayaan 
investasi dan modal kerja). Dengan demikian penggadai (rahin) akan memberikan bagi hasil (berdasarkan keuntungan) kepada (murtahin) sesuai dengan kesepakatan, sampai modal yang dipinjam terlunasi. (Iska dan Rizal, 2005 64).

Kedua akad di atas tidak mensyaratkan pengambilan manfaat atau hasil oleh penerima gadai (murtahin) dari lahan sawit yang digadaikan, sehingga pemilik lahan sawit (rahin) tetap berhak memanfaatkan lahan sawit tersebut.

3. Penebusan utang gadai sesuai dengan batas waktu yang diperjanjikan

Penebusan utang gadai sesuai dengan batas waktu yang telah diperjanjikan sesuai dengan kasus yang terjadi pada Bapak Marta sebagai pihak penggadai (rahin) dan Bapak Zulkani sebagai pihak penerima gadai (murtahin), dimana dalam perjanjian telah disebutkan bahwa rahin meminjam uang sebesar Rp. 30.000.000,- kepada murtahin dengan batas waktu pelunasan utang gadai selama 10 tahun dan ketika sampai pada jatuh tempo maka utang tersebut dianggap lunas. Seluruh dari hasil lahan sawit milik rahin menjadi milik murtahin selama perjanjian dan pelunasan utang diambil dari hasil lahan sawit tersebut.

Penebusan utang yang diambil oleh murtahin dari hasil lahan sawit setelah dikurangi biaya pengelolaan diperbolehkan selama tidak melebihi utang pihak rahin, dan sangat memberi kemudahan kepada rahin untuk melunasi utangnya kepada murtahin. Namun yang menjadi permasalahan adalah jangka waktu yang terlalu lama yaitu selama 10 tahun sehingga hasil lahan sawit tersebut bisa melebihi utang yang dipinjam sehingga menimbulkan pemanfaatan terhadap barang gadai.

Allah berfirman dalam surat AlBaqarah ayat 282 yang berbunyi:

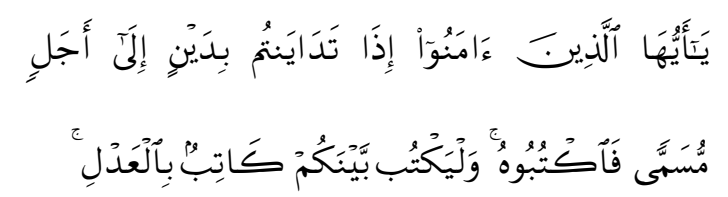

"Hai orang-orang yang beriman, apabila kamu bermu'amalah tidak secara tunai untuk waktu yang ditentukan, hendaklah kamu menuliskannya. dan hendaklah seorang penulis di antara kamu menuliskannya dengan benar". (QS. Al-Baqarah: 282). (Kementerian Agama RI, Al-Qur'an dan Terjemahannya, surat AlBaqarah: 282)

Ayat di atas menjelaskan bahwa tidak ada larangan untuk melakukan utang piutang, bahkan memberi utang 
sangatlah dianjurkan. Sebab, hal itu dapat membantu seseorang dari kesulitan yang dihadapi dalam masyarakat. Sedangkan hukum memberikan utang adalah sunnah, namun akan wajib hukumnya apabila menguntangi pada orang yang terlantar atau orang yang sangat membutuhkan. Sebab, pada prinsipnya setiap orang membutuhkan orang lain untuk memenuhi hajat hidupnya.

Mengenai adanya pemanfaatan terhadap barang gadai sesuai dengan kasus di atas pada dasarnya barang gadai tidak boleh diambil manfaatnya penerima/pemegang gadai, kecuali mendapat izin dari masing-masing pihak yang bersangkutan. Sebab hak pemilik barang tidak memiliki secara sempurna yang memungkinkan ia melakukan perbuatan hukum sewaktu-waktu, misalnya mewakafkan, menjual, dan lain sebagainya. Sedangkan hak penerima/pemegang gadai terhadap barang tersebut hanya pada keadaan atau sifat keberadaaannya yang mempunyai nilai, tetapi tidak pada guna dan pemanfaatan/ pemungutan hasilnya.

Pemegang gadai hanya berhak menahan barang gadai tetapi tidak berhak menggunakan atau memanfaatkan hasilnya, sebagaimana pemilik barang gadai tidak berhak menggunakan barangnya itu. Tetapi sebagai pemilik apabila barang yang digadaikan itu mengeluarkan hasil, maka hasil tersebut menjadi miliknya. Mayoritas ulama mengharamkan pengambilan manfaat terhadap barang gadai karena termasuk dalam kategori riba qardh (Zuhdi, 1997: 118). Sebagaimana kaidah fiqh yang berbunyi:

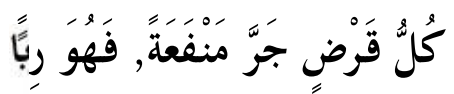

Setiap utang piutang yang ditarik manfaat di dalamnya, maka itu adalah riba. (Al-Ats Qalani, 1993: 56)

Menurut hemat penulis penerima gadai (murtahin) boleh mengambil hasil dari lahan sawit tersebut untuk melunasi utang penggadai (rahin) sesuai dengan perjanjian dengan syarat diizinkan oleh rahin dan tidak melebihi dari utang rahin. Sehingga memudahkan bagi rahin untuk melunasi utangnya kepada murtahin.

4. Penjualan barang gadai (marhun)

Penjualan barang gadai terjadi pada kasus Bapak Suparman sebagai penggadai (rahin) dan Bapak Hasan Basri selaku penerima gadai, dimana Bapak Hasan Basri telah menjual lahan sawit milik Bapak Suparman kepada Bapak Rajuddin tanpa sepengetahuan dari pemilik lahan sawit tersebut yaitu Bapak Suparman. 
Seandainya penerima gadai terlanjur memanfaatkannya, serta menjual barang gadai atau menyewakannya tanpa seizin pemiliknya, maka menurut Imam Syafi'i dan Imam Hambali penjualan dan sewa menyewa tersebut batal dan tidak sah. Adapun menurut Imam Hanafi dan Imam Malik, penjualan dan sewa menyewa tersebut hukumnya tergantung kepada pemilik barang, apabila ketika pemilik mengetahui kemudian menyetujuinya, maka sah penjualan atau sewa menyewa itu, apabila tidak maka batal dan tidak sah. (Qudamah, 1997: 89)

Pendapat terakhir inilah (Imam Hanafi dan Imam Malik) yang kuat dengan dasar sebuah hadis yang dikeluarkan oleh Imam Bukhari, bahwasanya seorang sahabat bernama Urwah al-Bariqi radiyallahu 'anhu pernah dititipi Rasulullah Shollallahu 'alaihi Wasallam satu dinar untuk membeli satu ekor kambing kurban, lalu Urwah pergi ke pasar hewan membeli dua ekor kambing seharga satu dinar, kemudian sebelum kembali kepada Nabi Shollallahu 'alaihi Wasallam ia menjual satu ekor kambing seharga satu dinar, lalu datang kepada beliau membawa satu ekor kambing dan uang satu dinar, dan tatkala Nabi Shollallahu 'alaihi Wasallam mengetahuinya, beliau tidak mengingkarinya, bahkan
Rasulullah mendoakan keberkahan buat Urwah. Hadis ini menunjukkan apabila seseorang menjual atau membeli sesuatu tanpa persetujuan pemiliknya yang sah, kemudian pemiliknya yang sah ketika tahu lalu menyetujuinya, maka sah transaksi tersebut, dan apabila tidak menyetujuinya maka batal dan tidak sah.

Menurut ketentuan syariat bahwa apabila masa yang telah diperjanjikan untuk pembayaran utang telah terlewati maka si berutang berkewajiban untuk membayar utangnya. Namun seandainya si berutang tidak punya kemauan atau tidak mempunyai uang untuk mengembalikan pinjamannya hendaklah ia memberikan izin kepada penerima gadai untuk menjual barang gadai tersebut. (Shahar, 2015: 5). Dan seandainya izin ini tidak diberikan oleh si penggadai maka si penerima gadai dapat meminta pertolongan hakim untuk memaksa si pemberi gadai untuk melunasi utangnya atau memberikan izin kepada si penerima gadai untuk menjual barang gadai tersebut. (Wiharjanto, 2002: 97). Hal ini juga dijelaskan dalam Fatwa MUI DSN-MUI Nomor 25/DSNMUI/III/2002 tentang Rahn.

Hukum menggadaikan barang sebagai jaminan utang dalam bentuk Rahn dibolehkan dengan ketentuan 
sebagai berikut: (Dewan Syariah Nasional, 2002: 49)

1. Murtahin (penerima barang) mempunyai hak untuk menahan. Marhun (barang) sampai semua rahin (yang menyerahkan barang) dilunasi.

2. Marhun dan manfaatnya tetap menjadi milik rahin. Pada prinsipnya, marhun tidak boleh dimanfaatkan oleh murtahin kecuali seizin rahin, dengan tidak mengurangi nilai marhun dan pemanfaatannya itu sekedar pengganti biaya pemeliharaan dan perawatannya.

3. Pemeliharaan dan penyimpanan marhun pada dasarnya menjadi kewajiban rahin, namun dapat dilakukan juga oleh murtahin, sedangkan biaya dan pemeliharaan penyimpanan tetap menjadi kewajiban rahin.

4. Besar biaya pemeliharaan dan penyimpanan marhun tidak boleh ditentukan berdasarkan jumlah pinjaman.

5. Penjualan marhun.

a. Apabila jatuh tempo, murtahin harus memperingatkan rahin untuk segera melunasinya.

b. Apabila rahin tetap tidak dapat melunasinya, maka marhun dijual paksa/dieksekusi melalui lelang sesuai syariah. c. Hasil penjualan marhun digunakan untuk melunasi utang, biaya pemeliharaan dan penyimpanan yang belum dibayar serta biaya penjualan.

d. Kelebihan hasil penjualan menjadi milik rahin dan kekurangannya menjadi kewajiban rahin. (Dewan Syariah Nasional, 2002: 49).

Fatwa MUI DSN-MUI Nomor 25/DSN-MUI/III/2002 tentang Rahn butir ke-5 huruf d menyatakan bahwa kelebihan hasil penjualan menjadi milik rahin dan kekurangannya menjadi kewajiban rahin. Apabila penerima gadai telah menjual barang gadai tersebut ternyata ada kelebihan dari yang seharusnya dibayar oleh si penggadai, maka kelebihan tersebut harus diberikan kepada si penggadai. Sebaliknya sekalipun barang gadaian telah dijual dan ternyata belum dapat melunasi hutang si penggadai, maka si penggadai masih punya kewajiban untuk membayar kekurangannya.

Sayyid Sabiq mengatakan jika terdapat klausula murtahin berhak menjual barang gadai pada waktu jatuh tempo perjanjian gadai, maka ini dibolehkan. (Sabiq, 1971: 243). Argumentasi yang diajukan adalah bahwa menjadi haknya penerima barang gadai untuk menjual barang gadai tersebut. Pendapat ini berbeda dengan pendapat Imam Syafi'i yang 
memandang dicantumkannya klausula tersebut dalam perjanjian gadai adalah batal demi hukum.

Pada zaman tradisi Arab sebelum Islam datang, jika orang yang menggadaikan barang tidak mampu mengembalikan pinjamannya, maka hak kepemilikan barang gadai beralih ke pemegang gadai. Praktek semacam inilah yang kemudian dibatalkan oleh Islam. Hal ini tertuang dalam hadits dari Muawiyah bin Abdullah bin Ja'far bahwa seseorang mem-borg-kan sebuah rumah di Madinah untuk jangka waktu tertentu. Kemudian nasabnya lewat. Lalu si pemegang borg (murtahin) menyatakan bahwa "ini menjadi rumahku". Rasulullah kemudian bersabda: “ janganlah ia (pemegang gadaian) menutup hak gadaian dari pemiliknya (rahin) yang menggadaikan. Ia (murtahin) berhak memperoleh bagiannya dan dia (rahin) berkewajiban membayar gharamahnya" (HR. Asy-Safi'i, Al Atsram, dan Dharuqutni mengatakan sanadnya hassan muttashil. Ibnu Hajar dalam Bulughul Maram mengatakan para perawinya tsigat.

Hal ini disetujui juga oleh AlJaziri yang mengatakan bahwa jika rahin mensyaratkan marhun tidak dijual ketika utangnya jatuh tempo, maka rahn menjadi batal. Begitu pula jika murtahin mensyaratkan kepada rahin bahwa marhun menjadi milik murtahin jika rahin tidak membayar utangnya maka ini juga tidak sah (batal). (Al-Jaziri, 2001: 101).

Menurut penulis seharusnya penerima gadai melaksanakan sistem lelang barang gadai untuk mempermudah dalam menjual barang gadai yang sesuai dengan prinsip syariah. Pada prinsipnya, syariah membolehkan jual beli barang yang halal dengan cara lelang yang dalam istilah hukum ekonomi syariah atau fiqih muamalah disebut sebagai akad bai' muzayadah.

Praktek lelang (muzayadah) dalam bentuknya yang sederhana pernah dilakukan oleh Nabi SAW ketika didatangi oleh seorang sahabat dari kalangan Ashar meminta sedekah kepadanya. Lalu Nabi bertanya : "Apakah rumahmu ada suatu barang?" Sahabat tadi menjawab besar dari bahwa ia memiliki sebuah hiis (kain usang) yang dipakai sebagai selimut sekaligus alas dan sebuah qi'b (cangkir dari kayu) yang dipakai minum air. Lalu Beliau menyuruhnya mengambil kedua barang tersebut. Ketika ia meyerahlannya kepada Nabi, Beliau mengambilnya lalu menawarkannya: "Siapakah yang berminat membeli kedua barang ini?" Lalu seseorang menawar keduanya dengan harga satu dirham. Maka Beliau mulai meningkatkan penawarannya : "Siapakah yang mau 
menambahkannya lagi dengan satu dirham?" Lalu berkatalah penawar lain: "Saya membelinya dengan harga dua dirham" Kemudian Nabi menyerahkan barang tersebut kepadanya dan memberikan dua dirham hasil lelang kepada sahabat Anshar tadi. (HR. Abu Dawud, AnNasai dan Ibnu Majah). (Wiharjanto, 2002: 102).

Ibnu Qudamah, Ibnu Abdil Bar dan lainnya mengatakan adanya 'ijma (kesepakatan) ulama tentang bolehnya jual beli secara lelang bahkan telah menjadi kebiasaan dan berlaku di pasar umat Islam pada masa lalu. Sebagaimana Umar Bin Khatab juga pernah melakukannya, demikian pula karena umat membutuhkan praktik lelang sebagai salah satu cara dalam jual beli khsususnya praktek gadai (rahn). Pendapat ini dianut seluruh mazhab Hanafi, Maliki, Syafi'i, dan Hambali serta Dzahiri. Meskipun demikian, adapula sebagian kecil ulama yang keberatan seperti AnNakha'i dan Al-Auza'i. (Wiharjanto, 2002: 102).

Mencegah adanya penyimpangan yang tidak sesuai dengan prinsip syariah dan pelanggaran hak, norma, dan etika dalam praktik lelang. Syariat Islam memberikan panduan dan kriteria umum sebagai pedoman pokok, yaitu diantaranya: a. Transaksi dilakukan oleh pihak yang cakap hukum atas dasar saling sukarela ('antaradhin);

b. Objek lelang harus halal danbermanfaat;

c. Kepemilikian/Kuasa Penuh pada barang yang dijual;

d. Kejelasan dan transparansi barang yang dilelang tanpa adanya manipulasi;

e. Kesanggupan penyerahan barang dari sipenjual;

f. Kejelasan dan kepastian harga yang disepakati tanpa berpotensi menimbulkan perselisihan;

g. Tidak menggunakan cara yang menjurus kepada kolusi dan suap untuk memenangkan tawaran. (Wiharjanto, 2002: 102)

Jadi, menurut penulis penerima gadai (murtahin) tidak boleh menjual barang gadai tanpa izin penggadai (rahin) selaku pemilik barang gadai. Namun, apabila penggadai tidak memberikan izin, maka penerima gadai boleh menjual barang gadai sesuai dengan putusan hakim untuk melunasi utang penggadai dan biasanya dilakukan melalui lelang barang gadai (muzayadah). Apabila penjualan tersebut mempunyai sisa uang, maka harus diberikan kepada penggadai, namun sebaliknya apabila uang dari hasil penjualan lahan sawit tersebut ternyata kurang dari jumlah utang yang dipinjam, maka penggadai 
harus membayar sesuai dengan kekurangan utang tersebut.

5. Pemindahan hak milik barang gadai

Kata "kepemilikan" dalam bahasa Indonesia terambil dari kata "milik". Ia merupakan kata serapan dari kata "al-milk" dalam bahasa Arab. Secara etimologi kata "al-milk" artinya memiliki. Dalam bahasa Arab kata "almilkiyyah" berarti memelihara dan menguasai sesuatu secara bebas. Maksudnya, penguasaan seseorang terhadap sesuatu harta (barang atau jasa) yang membolehkannya untuk mengambil manfaat dengan segala cara yang dibolehkan oleh syara', sehingga orang lain tidak diperkenankan mengambil manfaat dengan barang tersebut kecuali dengan izinnya, dan sesuai dengan bentuk-bentuk muamalah yang diperbolehkan. Misalnya, Ahmad memiliki lahan sawit. Ini berarti bahwa lahan sawit itu dalam kekuasaan dan genggaman Ahmad. Dia bebas untuk memanfaatkan dan orang lain tidak boleh menghalangi dan merintanginya dalam menikmati hasil lahan sawit yang dimilikinya tersebut, kecuali setelah mendapat izin dari pemiliknya.

Sedangkan

pengertian "kepemilikan" menurut istilah berbagai ungkapan yang dikemukakan oleh para ahli, namun secara esensial seluruh definisi itu pada prinsipnya sama. Misalnya, Muhammad Mushthafa al- Salaby mendefinisikan al-milk sebagai pengkhususan (keistimewaan) atas sesuatu benda yang menghalangi orang lain bertindak atasnya dan memungkinkan pemiliknya melakukan tindakan secara langsung terhadap benda itu, selama tidak ada halangan syara".

Sebab-sebab kepemilikan harta adalah sebab yang menjadikan seseorang memiliki harta tersebut, yang sebelumnya tidak menjadi hak miliknya. Sebab pemilikan harta itu telah dibatasi dengan batasan yang telah dijelaskan oleh syara'. Menurut syari'at Islam setidaknya ada lima sebab kepemilikan (asbab altamalluk) yang dijadikan sebagai sumber daya ekonomi, yaitu:

a. Bekerja (al-'amal)

Bentuk-bentuk kerja yang disyariatkan, sekaligus bisa dijadikan sebagai sebab pemilikan harta, antara lain:

1) Menghidupkan Tanah Mati (ihya' almawaat)

Tanah mati adalah tanah yang tidak ada pemiliknya, dan tidak dimanfaatkan oleh seorangpun. Sedangkan yang dimaksud dengan menghidupkannya adalah mengolahnya dengan menanaminya, baik dengan tanaman maupun pepohonan, 
atau dengan mendirikan bangunan di atasnya. Dengan adanya usaha seseorang untuk menghidupkan tanah, berarti usaha orang tadi telah menjadikan tanah tersebut menjadi miliknya.

2) Menggali Kandungan Bumi

Kategori bekerja adalah menggali apa terkandung di dalam perut bumi, yang bukan merupakan harta yang dibutuhkan oleh suatu komunitas (publik), atau disebut rikaz. Adapun jika harta temuan hasil penggalian tersebut merupakan hak seluruh kaum muslimin, maka harta galian tersebut merupakan hak milik umum (collective property). Apabila harta tersebut asli, namun tidak dibutuhkan oleh suatu komunitas (publik), semisal ada seorang pemukul batu yang berhasil menggali batu bangunan dari sana, ataupun yang lain, maka harta tersebut tidak termasuk rikaz, juga tidak termasuk hak milik umum (collective property), melainkan termasuk hak milik individu (private property).

3) Berburu

Berburu termasuk dalam kategori bekerja. Misalnya berburu ikan, mutiara, batu pemata, bunga karang serta harta yang dipeloleh dari hasil buruan laut lainnya, maka harta tersebut adalah hak milik orang yang memburunya,

4) Makelar (Samsarah)

Simsar (broker/pialang) adalah sebutan bagi orang yang bekerja untuk orang lain dengan upah, baik untuk keperluan menjual maupun membelikan. Sebutan ini juga layak dipakai untuk orang yang mencarikan (menunjukkan) orang lain. Makelar (samsarah) termasuk dalam kategori bekerja yang bisa dipergunakan untuk memiliki harta, secara sah menurut syara'.

5) Mudharabah

Mudharabah adalah perseroan (kerjasama) antara dua orang dalam suatu perdagangan. Dimana, modal (investasi) finansial dari satu pihak, sedangkan pihak lain memberikan tenaga ('amal). Dalam sistem mudlarabah, pihak pengelola memiliki bagian pada harta pihak lain karena kerja yang dilakukannya. Sebab, mudharabah bagi pihak pengelola termasuk dalam kategori bekerja serta merupakan salah satu sebab kepemilikan.

6) Musyaqqah 
Musyaqqah adalah seseorang menyerahkan pepohonan (kebun) nya kepada orang lain agar ia mengurus dan merawatnya dengan mendapatkan konpensasi berupa bagian dari hasil panennya. Dengan demikian, musyaqqah termasuk dalam kategori bekerja yang telah dinyatakan kebolehannya oleh syara'.

7) Ijarah

Ijarah adalah pemilikan jasa dari seorang ajïr (orang yang dikontrak tenaganya) oleh mustajir (orang yang mengontrak tenaga), serta pemilikan harta dari pihak musta’jir oleh seorang ajiir.

b. Pewarisan (al-irts)

Sebab-sebab pemilikan harta adalah pewarisan, yaitu pemindahan hak kepemilikan dari orang yang meninggal dunia kepada ahli warisnya, sehingga ahli warisnya menjadi sah untuk memiliki harta warisan tersebut. Berdasarkan firman Allah Swt dalam surat An-Nisa ayat 11 :

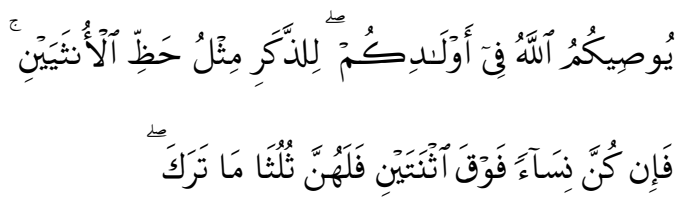

"Allah mensyari'atkan bagimu tentang (pembagian pusaka untuk) anak-anakmu. yaitu : bahagian seorang anak lelaki sama dengan bagahian dua orang anak perempuan dan jika anak itu semuanya perempuan lebih dari dua, Maka bagi mereka dua pertiga dari harta yang ditinggalkan".

Dengan demikian, pewarisan adalah salah satu sebab pemilikan yang disyariatkan. Oleh karena itu, siapa saja yang menerima harta waris, maka secara syara' dia telah memilikinya. Jadi waris merupakan salah satu sebab pemilikan yang telah diizinkan oleh syari'at Islam.

c. Pemberian harta negara kepada rakyat

Kategori sebab kepemilikan adalah pemberian negara kepada rakyat yang diambilkan dari harta baitul maal, dalam rangka memenuhi kebutuhan hidup, atau memanfaatkan kepemilikan. Mengenai pemenuhan hajat hidup adalah semisal memberi mereka harta untuk menggarap tanah pertanian atau melunasi hutanghutang. Umar bin Khaththab telah membantu rakyatnya untuk menggarap tanah pertanian guna memenuhi hajat hidupnya, tanpa meminta imbalan. Kemudian syara' memberikan hak kepada mereka yang mempunyai hutang berupa harta zakat. Mereka akan diberi dari bagian zakat tersebut untuk melunasi hutang-hutang mereka, 
apabila mereka tidak mampu membayarnya.

d. Harta yang diperoleh tanpa kompensasi harta atau tenaga Kategori sebab kepemilikan adalah perolehan individu, sebagian mereka dari sebagian yang lain, atas sejumlah harta tertentu tanpa kompensasi harta atau tenaga apa pun. Dalam hal ini mencakup lima hal:

1) Hubungan pribadi, antara sebagian orang dengan sebagian yang lain, baik harta yang diperoleh karena hubungan ketika masih hidup, mseperti hibah dan hadiah, ataupun sepeninggal mereka, seperti wasiat.

2) Pemilikan harta sebagai ganti rugi (kompensasi) dari kemudharatan yang menimpa seseorang, semisal diyat orang yang terbunuh dan diyat luka karena dilukai orang.

3) Mendapatkan mahar berikut halhal yang diperoleh melalui akad nikah.

4) Luqathah (barang temuan).

5) Santunan yang diberiakan kepada khalifah dan orang-orang yang disamakan statusnya, yaitu samasama melaksanakan tugastugas termasuk kompensasi kerja mereka, melainkan konpensasi dari pengekangan diri mereka untuk melaksanakan tugas-tugas negara.

Penulis dapat menyimpulkan bahwa pemindahan kepemilikan harta melalui praktek gadai dilarang dalam hukum Islam khususnya hukum ekonomi syariah, karena akad gadai adalah akad tabarru' (tolong menolong) bukan akad pemindahan hak milik untuk mendapatkan keuntungan tertentu.

\section{PENUTUP}

\section{Kesimpulan}

Berdasarkan hasil penelitian tentang Analisis Hukum Ekonomi Syariah terhadap Praktek Gadai Lahan Sawit di Kecamatan Gunung Tuleh dapat disimpulkan bahwa dalam praktek gadai lahan sawit di Kecamatan Gunung Tuleh Kabupaten Pasaman Barat dilihat dari segi akadnya tidak sesuai dengan ketentuan hukum Islam khususnya hukum ekonomi syariah. Tidak sesuai akad tersebut terjadi pada sighat akad pada ijab kabl yang mensyaratkan pemanfaatan barang gadai, adanya biaya tambahan yang harus diberikan penggadai (rahin) dengan sejumlah uang tertentu dalam melunasi utangnya. Hukum ekonomi syariah menyebutkan bahwa shighat gadai tidak boleh digantungkan dengan syarat, dan tidak disandarkan kepada 
masa yang akan datang. Apabila akad gadai (rahn) digantungkan dengan syarat atau disandarkan kepada masa yang akan 69ating, maka akad akan fasid (rusak), seperti adanya biaya tambahan yang harus diberikan dalam penebusan utang gadai yang dicantumkan dalam akad dengan mengacu kepada kaidah fiqh "setiap utang yang menarik manfaat, maka ia termasuk riba".

\section{Saran}

1. Kepada masyarakat Kecamatan Gunung Tuleh Kabupaten Pasaman Barat, agar supaya lebih memperhatikan aturan-aturan dalam bermuamalah khususnya gadai menggadai barang agar tidak melenceng dari ketentuan syariat Islam khususnya praktek riba.

2. Untuk meminimalisir masalah dalam praktek gadai tersebut lebih baik menjadikan sertifikat sebagai barang jaminan, bukan manfaat yang melekat pada barang jaminan tersebut.

3. Proses akad gadai yang terjadi di Kecamatan Gunung Tuleh Kabupaten Pasaman Barat lebih baik diubah menjadi akad sewamenyewa.

\section{KEPUSTAKAAN ACUAN}

Al-Dardiri, t.th. Al-Syarhu Al-Shagir, Mesir: Dar El-Ma'arif
Al-Matluwi, H. K. t.th. Fiqh alMuamalat 'ala Mazhab al-Imam Malik, Kairo: al-Majli al-A'la asysyu un Al-Islamiyah

Al-Ats Qalani, S. 1993. Terjemah Bulughul Maram, Surabaya: Usana offset printing

Al-Samarqandy, Tuhfatu Al-Fuqaha' Li Al-Samarqandy, Juz II, Beirut: Dar Al-Kutub AlIlmiyyah

Anshori, A. G. 2005. Gadai Syariah di Indonesia, Yogyakarta: Gadjah Mada

2010. Pokok-pokok Perjanjian Islam di Indonesia. Yogyakarta: Citra Media

Arikunto, S. 1996. Prosedur Penelitian Pendekatan Suatu Praktek, Jakarta: Rineka Cipta

Azwar, S. 2007. Hukum Perjanjian Syariah, Jakarta: RajaGrafindo Persada

Az-Zuhaili, W. 2001. Fiqh Islam wa Adillatuhu, Jilid VI, Jakarta : Gema Insani Darul Fikr.

Djuwaini, D. 2010. Pengantar Fiqh Muamalah, Yogyakarta: Pustaka Pelajar

Ghazaly, A. R. 2010. Fiqh Muamalat, Jakarta: Kencana

Hadi, M. S. 2003. Pegadaian Syariah, Jakarta: Selemba Diniyah 
Hanafi, t.t. Fiqhul Akbar, Beirut: Dar Al-Kutub Al-Ilmiyah

Hanbali, I. 1996. Syarah Ushulus Sunnah, Beirut: Maktabah Ibnu Taimiyah

Haroen, N. 2000. Fiqh Muamalah, Jakarta: Gaya Media Pratama

Hasan, M. 2004. Berbagai Transaksi Dalam Islam, Jakarta: PT Raja Grafindo Persada

Hassan, A. 1987. Terjemahan Nailul Authar Jilid IV, Surabaya: PT Bina Ilmu, 1785
Iska, S. 2012. Sistem Perbankan Syariah di Indonesia dalam Perspektif Ekonomi, Yogyakarta: Fajar Media Press

Jusoff, K. 2013. The Concept and Challange of Islamic Pawn Broking (Ar-Rahnu), Jurnal, Middle-East, Vol. XIII, Issn: 1990-9233

Muhammad, F. 2016. Marketing Mixed Strategy and Its Relationship in Islamic Pawning Products Selection at Ar-Rahnu, Jurnal, HR Mars, Vol. VI, Issn: 2222-699o 